\title{
State of Tectonic Stress in Shillong Plateau of Northeast India
}

Santanu Baruah* ${ }^{1}$, Saurabh Baruah ${ }^{1}$, Sowrav Saikia ${ }^{2}$, Mahesh N. Shrivastava, Antara Sharma ${ }^{1}$ C. D. Reddy ${ }^{4}$, and J. R. Kayal ${ }^{5}$

1. Geoscience Division, CSIR-North East Institute of Science and Technology, Jorhat-785006, Assam, India;

2. Ministry of Earth Sciences, Govt. of India, New Delhi, India

3. National Research Center for Integrated Natural Disaster Management, Santiago, Chile

4. Indian Institute of Geomagnetism, Navi-Mumbai, 410218, India;

5. Institute of Seismological Research, Gandhinagar 382009, Gujarat, India.

\begin{abstract}
Tectonic stress regime in the Shillong plateau, northeast region of India, is examined by stress tensor inversion. Some 97 reliable fault plane solutions are used for stress inversion by the Michael and Gauss methods. Although an overall NNW-SSE compressional stress is observed in the area, the stress regime varies from western part to eastern part of the plateau. The eastern part of the plateau is dominated by NNE-SSW compression and the western part by NNW-SSE compression. The NNW-SSE compression in the western part may be due to the tectonic loading induced by the Himalayan orogeny in the north, and the NNE-SSW compression in the eastern part may be attributed to the influence of oblique convergence of the Indian plate beneath the Indo-Burma ranges. Further, Gravitational Potential Energy (GPE) derived stress also indicates a variation from west to east.
\end{abstract}

Keywords: Tectonic stress, stress tensor inversion, stress rotation, intra-plate zone, deviatoric stress, GPE stress. 
*Corresponding author: santanub27@gmail.com

\section{Introduction}

The Shillong plateau in North East Region, India (here after called NER, India), is one of the most active tectonic zones in the world; the region is buttressed by the Himalaya collision zone to the north and Indo-Burma subduction zone to the east (Fig.1). While the former accommodates the convergence between the India and Eurasia plates, the latter accommodates an oblique convergence between the Indian plate and Burmese micro-plate, respectively (e.g. Chen and Molnar, 1990; Nandy, 2001, Clark and Bilham, 2008, Kayal, 2008). The southern boundary of the plateau is defined by the long E-W trending Dauki fault that separates the Shillong massif and the Bengal basin sediments; the Bengal basin is considered to be the largest deltaic basin in the World. The western boundary of the plateau is demarcated by the N-S trending Dhubri fault. The Shillong plateau is considered to be the largest ( 400 km long) intraplate active basement fold structure in the World, 5 to 10 times larger than that in the Laramide orogeny of the western US or the Sierras Pampeanas of the Andean orogen (Allmendinger et al., 1983; Clark and Bilham, 2008). There is a general observation that the tectonic stress within Indian plate is mainly due to the plate movement, but the stress direction varies spatially as well as with depth (Gowd and Rao, 1992; Rajendran et al., 1992). An average N-S compression in the eastern Himalaya thrust belt and NE-SW compression in the Indo-Burma ranges are reported from fault plane solutions of earthquakes by several authors (e.g. Le Dian et al., 1984; Ni et al., 1989; Chen and Molnar, 1990). Existence of complicated thrust / reverse fault systems to the northern and southern boundary of the Shillong plateau (Bilham and England, 2001; Clark and Bilham, 2008) and strike-slip fault systems in its eastern as well as western boundary make the 
intraplate plateau tectonics enigmatic and more so in understanding its stress pattern (e.g. Nandy, 2001; Kayal et al., 2012).

An isolated fault plane solution may not represent a regional tectonic stress pattern. In such a situation, large number of fault plane solutions are inverted to estimate the most plausible regional stress pattern and its spatial variation (e.g. Angelier, 1984; Zoback and Zoback, 1980; Chen and Molnar, 1983). In NER India, Angelier and Baruah (2009) first made such attempt and depicted the stress variation for nine selected tectonic blocks. Their data set for the Shillong plateau area was, however, much scanty with only 25 fault plane solutions, and they could not resolve any spatial variation of the stress pattern in the plateau area. Here, we have obtained some 97 fault plane solutions of recent earthquakes $\left(2.5 \leq \mathrm{M}_{\mathrm{D}} \leq 5.3\right.$, where $\mathrm{M}_{\mathrm{D}}$ is duration magnitude) (Fig 1), and made a comprehensive study of spatial stress variation. In addition, we examined the Gravitational Potential Energy (GPE) (Bucher, 1956), i.e. the stress change associated with the surface elevation as well as with the sub-surface density distribution (e.g. Flesch and Kreemer, 2010). These combined results shed new light in understanding the tectonics and stress regime of the plateau, which are found to be different from west to east within the plateau.

\section{Tectonic Setting and Large Earthquakes}

The NER India is marked as zone V $(\mathrm{PGA} \sim 0.37 \mathrm{~g})$ in the seismic zoning map of India compiled by the Bureau of Indian Standards (BIS, 2002), that produced two great earthquakes, the 1897 great Shillong earthquake (Ms 8.7) (Oldham, 1899), revised Mw 8.1 (Bilham and England, 2001), at the northern boundary of the plateau and the 1950 great Assam earthquake (Ms 8.7) in the eastern syntaxis zone (Tandon, 1954) (Fig. 1). In addition to the two great earthquakes, some 
20 large earthquakes $(M \geq 7.0)$ are reported in the region since the 1897 great earthquake (Kayal, 2008); most of these occurred beneath the Indo-Burma ranges. In addition to the 1897 great earthquake Mw 8.1, the Shillong plateau and its adjoining Bengal basin produced five large intraplate earthquakes $(M>7.0)$, and it is considered to be the most active intraplate region in India (Kayal, 2008). The Shillong plateau, a part of the Indian shield, is fragmented by the long NW-SE trending Kopili fault and separated the Mikir massif to the northeast (Fig. 1). The Kopili fault produced two large earthquakes; one in 1869 (Mw 7.7; Szeliga et al., 2010) and the other in $1943\left(\mathrm{M}_{\mathrm{L}}\right.$ 7.1), respectively (Nandy, 2001; Kayal, 2008). To the west of the plateau lies the long N-S trending Dhubri fault that produced the 1930 large earthquake $\left(\mathrm{M}_{\mathrm{L}}\right.$ 7.1). In addition to these, two more large earthquakes were recorded in the intraplate Bengal basin to the south of the plateau, the 1923 earthquake $\left(M_{L}\right.$ 7.3) at the northeast end of the subsurface hinge zone and the 1918 earthquake $\left(\mathrm{M}_{\mathrm{L}}\right.$ 7.6) at the Sylhet fault zone (Fig.1). The subsurface hinge zone, identified by gravity survey, is marked as the boundary between the continental crust to the west and the oceanic crust to the east, and the Sylhet fault, on the other hand, is identified as a strike slip fault along the Sylhet trough (Verma et al. 1976; Kayal, 2008).

Although no fault plane solution was available, the 1897 great earthquake was interpreted to be a thrust event by a north dipping thrust fault (Oldham, 1899). Based on microearthquake survey, Kayal (1987, 2001) and Kayal and De (1991) supported Oldham's (1899) interpretation. Bilham and England (2001), however, based on GPS data proposed a pop-up tectonic model of the plateau, and argued that the 1897 great event occurred on a south dipping fault at the northern boundary of the plateau; they named it Oldham fault (Fig. 1). They further argued that the Shillong plateau earthquakes are caused by the pop-up tectonics between the south dipping 
Oldham fault and north dipping Dauki fault. Pop-up tectonics of the plateau was, however, first hypothesized by Rao and Kumar (1997); they proposed that uplift of the plateau is facilitated by the Dauki fault to the south, Brahmaputra (river) fault to the north, Dhubri fault to the west and Disang thrust to the east (Fig. 1). In addition to these, three major seismically active faults are mapped in the study area. These are: Dapsi thrust and Barapani shear zone within the plateau (Kayal, 1987; Kayal and De, 1991 and Kayal, 2001) and the long NW-SE trending Kopili fault that separates the Shillong massif from the Mikir massif (Kayal et al., 2006 and 2012). The NWSE trending Dapsi thrust in the western part of the Shillong plateau separates the Cenozoic to the north and Tertiary to the south (Kayal, 1987; Yin et al., 2010). The Barapani shear zone in the eastern part of Shillong plateau, on the other hand, separates the Cenozoic to the west and Proterozoic Shillong Gropu to the east (Nandy, 2001). Kayal $(1987,2001)$ and Kayal et al. (2006 and 2012) reported that the Dapsi thrust is seismogenic and dipping towards north; the near vertical Dauki fault, on the other hand, is seismically not much active. Hiller and Elahi (1988) and Nandy (2001) considered the Dauki fault as a south-directed normal fault, whereas Johnson and Alam (1991) considered it as a north-directed low-angle $\left(5-10^{\circ}\right)$ thrust fault. Few workers suggested that the Dauki fault should be considered as an up thrust fault (e.g. Murthy et al., 1969; Molnar, 1987; Murphy and Staff BOGMC, 1988; Chen and Molnar, 1990). Lohmann (1995) suggested that the Dauki fault at greater depth is a high-angle reverse fault, but near the surface an apparent right-lateral strike-slip fault. Thus complexities on the northern boundary faults (like Brahmaputra fault and Oldham fault) and the southern boundary faults (like Dapsi thrust and Dauki fault) are still debated. 


\section{Data Analaysis}

We used 97 fault plane solutions to accomplish the stress tensor inversion. Epicenters of the selected 97 earthquakes are shown in Fig. 2, and other details are given in Table 1. Out of the 97 fault plane solutions, 51 solutions are from published literature and one solution from the Global CMT catalog. The remaining 45 solutions are obtained in this study using local broadband network data recorded during 2001-2009 (Figs 1 and 3). These 45 earthquakes are recorded by at-least four seismic stations with good azimuthal coverage as well as with clear P-wave and Swave onsets. Since estimation of stress field is independent of magnitude or size of earthquakes (Angelier, 1975, 1984; Michael, 1984, 1987; Angelier and Baruah, 2009), we consider fault plane solutions of lower magnitude (M 2.5+) events also. Fault plane solutions of lower magnitude events have been successfully used for stress inversion by many authors (e.g., Fan and Wallace, 1991; Dreger and Helmberger, 1993; Herrmann, 2002; Mancilla et al., 2002; Dreger, 2003; Ristau et al., 2003, 2005; Scarfi et al., 2003; Musumeci et al., 2005; Tan et al., 2006; Zhu et al., 2006; Herrmann, 2008; Herrmann et al., 2008; D’Amico et al., 2008, 2010, 2011)

The 45 selected events $\left(2.5 \leq M_{D} \leq 4.3\right)$, which were recorded by local broadband network, are relocated by Baruah et al. (2012) using the HYPOCENTER program of Lienert et al. (1986) with the crustal velocity model of Bhattacharya et al. (2005). Uncertainties involved in estimates of hypocenters ranged from $0 \mathrm{~km}$ to $5.5 \mathrm{~km}$ with an average error of $\sim 4.0 \mathrm{~km}$ in depth and $\sim 3.0$ $\mathrm{km}$ in epicenter. Focal mechanisms of these 45 events are determined using the ISOLA code of Zahradink et al. (2001 and 2005). The ISOLA code is based on multiple point-source representation and iterative deconvolution method (Kikuchi and Kanamori, 1991). In the process, 
complete velocity records are used without selecting any particular phase. The earthquakes recorded by the digital broadband stations are selected on the basis of high signal to noise ratio and clear records of $\mathrm{P}$ and $\mathrm{S}$ arrivals. The 3-component digital records are first converted into displacement waveforms. The displacement waveforms are then low pass filtered below the corner frequency in order to remove any offset. The high frequency components are excluded because it is difficult to model high frequency components as it requires a precise knowledge of detailed subsurface crustal velocity model. Subsequently resampling of records from a frequency of $100 \mathrm{~Hz}$ to $33 \mathrm{~Hz}$ is carried out using transfer function of the seismometer. Necessary DC removal and trend line removal are also performed. Green's functions are then computed in the complex spectral domain using the suitable crustal velocity model pertinent to the region at a point source by Discrete Wave number (DW) method (Bouchan, 1981) using the program AXITRA (Coutant, 1989). The Green's functions are then convolved with appropriate instrument response and source time function. We estimated moment tensor solutions based on a point source model and simple triangular source time function. The triangular source time function shows a varying duration $(0.2$ to $0.6 \mathrm{sec}$.) with an increment of $0.1 \mathrm{sec}$. While calculating the Green's function, the position of the epicenters are kept fixed. A fine grid search of the strike, dip and rake is performed for the best depth and moment. The time step in the grid search is identical with a sampling interval of $0.01 \mathrm{sec}$. The inversion is performed in a frequency band of $0.03-0.05 \mathrm{~Hz}$. The final validation of the best fitting solutions was accomplished by comparing the observed and synthetic amplitude waveform.

The velocity model has an important role as an input to the inversion program. Several researchers (e.g., Gupta et al., 1984; Mukhopadhayay et al., 1997; Parvez et al., 2003; Kumar et 
al., 2004; Mitra et al., 2005; Bhattacharya et al., 2005 and 2008) have presented velocity model for NER, India by using different seismological and geophysical methods. We have tested sensitivity of the most used models for the fault plane solutions (Fig. 4). It is found that the models are sensitive mostly in terms of the Double Couple Percentage (DC\%) and correlation value. The strike, dip and rake angles also vary with each model. The solutions obtained using the Bhattacharya et al. (2005) model, which is based on 3D seismic tomography, show high DC\% and high correlation values (Fig. 4). We have exemplified inversion results for two events, the event 35 (Table 1 and Fig. 5a) with Mw 3.8 and the event 49 (Table 1 and Fig. 5b) with Mw 3.8. The results show a good agreement between the observed and synthetic seismograms.

It is always good to compare the fault plane solution obtained by wave form inversion using local broadband network data with that obtained by Global CMT solution. The 45 solutions obtained in this study are, however, not listed in the Global CMT catalog, thus could not be compared directly. The fault plane solutions which are taken from published papers were mostly derived from P- wave first-motion data. However, we could make an effective comparison indirectly. Stress field is examined separately utilizing the old published solutions and the new waveform inversion solutions. The results are found to be in good agreement. This test also verifies that we could use the old and new solutions together to examine the stress field variation in the study area.

\subsection{Fault Plane Solutions}

Chen and Molnar (1990) studied six earthquakes in the Shillong plateau by inversion of long period $\mathrm{P}$ and SH waveforms. They observed mixture of thrust and strike-slip faulting with P-axes 
oriented NNE-SSW. Kayal (1987) presented two composite solutions from two cluster of events in the plateau area and these solutions show reverse faulting with strike-slip component. Nandy and Dasgupta (1991) studied two fault plane solutions that show reverse faulting. Mukhopadhyay et al. (1993) reported two reverse and two strike-slip fault-plane solutions. Angelier and Baruah (2009) studied 25 fault plane solutions in the Shillong plateau using the local broadband network data, and showed mostly reverse and strike slip faulting. One Global CMT solution of an earthquake of 1999, Mw 5.2 was reported with a strike-slip solution. In this study we determined 45 solutions by waveform inversion using the local permanent broadband network data; these solutions show mostly thrust and strike-slip faulting with a few normal faulting mechanisms (Fig. 3). Three N-S cross sections (A-A', B-B' and C-C'), from west to east of the plateau (Fig. 1), are studied to examine variation in depth of the events and variation in source mechanisms; the results are shown in Figs 6 a, b and c.

\subsection{Stress Tensor Inversion}

Stress tensor inversion is carried out using the above 97 fault plane solutions. We used two methods, Michael (1984 and 1987) method and Gauss method (Zalohar and Vrabec, 2007) for the inversion analysis. The algorithm of Michael method uses the statistical method of bootstrap resampling and allows determining the orientation of three principal stresses $\left(\sigma_{1}=\right.$ maximum, $\sigma_{2}=$ intermediate and $\sigma_{3}=$ minimum) as well as a relative stress magnitude $\phi=\left(\sigma_{1}-\sigma_{2}\right) /\left(\sigma_{1}-\sigma_{3}\right), 0<\phi<1$. These parameters are determined by finding the best fit stress tensor to the observed solution. Assumptions made for the input data are: (i) stress is uniform in the area during the observed time interval, (ii) the earthquakes are shear-dislocations on preexisting faults, and (iii) slip occurs in the direction of the resolved shear stress on the fault plane. 
The Gauss method also involves the concept of the best-fit stress tensor. In this method, a new function called "compatibility function" is defined as a Gaussian function that depends on the compatibility measure taking into account two factors: (i) the angular misfit between the resolved shear stress and actual direction of movement on the fault plane, and (ii) the ratio between the normal and shear stress on the fault plane. The results of stress tensor inversions are illustrated in Figs 7a, b and c and other details are given in Tables 2, 3 and 4.

For the whole data set, the Michael method estimates $\sigma_{1}$ with azimuth $166^{\circ}$ and plunge $12^{\circ}$, and $\sigma_{3}$ with azimuth $310^{\circ}$ and plunge $74^{\circ}$. The $\phi$ value is found to be 0.2 . The Gauss method estimates the $\sigma_{1}$ with $164^{\circ}$ azimuth, $23^{\circ}$ plunge, and $\sigma_{3}$ with $295^{\circ}$ azimuth and $57^{\circ}$ plunge. The $\phi$ value is 0.2 . The Gauss method estimates approximate values of principal stresses as $1.03,0.27$ and 0.07 , respectively. On an average, the $\sigma_{1}$ is found to be consistent along NNWSSE (Table 2 and Fig. 7a). The results indicate that there is an extensional stress along ENE direction. The $\phi$ value 0.2 indicates that the extension along the intermediate principal axis is equal to that of extension along the minimum principal axis. The inversion results, however, clearly indicate that the area is under a compressional stress regime.

\subsection{Spatial Variation of Stress}

Two distinct clusters of events are observed in the study area, one N-S trending cluster (cluster a) to the west and one NE-SW trending cluster (cluster b) in the east (Fig. 2). We have examined variation of the stress pattern, if any, for these two cluster zones by both the methods, Michael 
and Gauss. Some 58 fault plane solutions are considered in the cluster a, and 24 fault plane solutions in the cluster b. The scattered events which are not in the cluster zones are not considered. Both the methods show a NNW-SSE compression in the cluster zone "a" and a NNE-SSW compression in the east in cluster b (Fig. 7 b). This observation clearly indicates a spatial variation of the tectonic stress within the plateau area.

The stress orientations in the two cluster zones ( $a$ and b) have been tested by computing probability density function of the compressive stress axes. This has been carried out by differencing all pairs of azimuths in bootstrap runs for the two clusters to produce a probability density function of the rotation angle and then seeing how much of it falls on the positive or negative side of zero (Michael, 1987). The most obvious difference is a rotation of the compressional stress axis about the vertical. The difference in azimuth of the compressional axis quantifies this rotation. The probability density function of this rotation is shown in Fig. 8 .

\subsection{Stress pattern as a function of depth}

Most of the earthquakes in the Shillong plateau occur in the lower crust, at a hypocentral depth 10-30 km, but some events at deeper depth 40 - $60 \mathrm{~km}$ are also evident (Figs 6a, b and c). Based on distribution of foci, two distinct seismogenic zones at depth may be visualized; one from surface to $30 \mathrm{~km}$ depth and the other below $30 \mathrm{~km}$. The orientations of stresses resulting from inversion are given in Table 3. Some 51 solutions are available for the events at depth range 0-30 $\mathrm{km}$ while 27 solutions at deeper depth $(>30 \mathrm{~km})$. It is found that the stress orientation does not change with depth; in both the depth ranges the compressive axis is along NNW-SSE (Fig. 7c). 
Besides this, Gauss method indicates that there exists extensional intermediate principal axis along ENE-WSW in both the depth ranges. The parameter $\phi=2$ indicates that the extension along intermediate and minimum principal axes is nearly equal. The probability density function of rotation is tested at the two depth ranges, but this rotation is not statistically significant. The results remain the same at two different depth ranges for the events of eastern as well as western part.

\section{Deviatoric stress from GPE}

The total stress tensor at any point in the lithosphere can be considered to be composed of isotropic part and anisotropic "deviatoric" part. The isotropic part of the stress tensor is an invariant quantity corresponding to the mean normal pressure (e.g., Batchelor, 1967; Jaeger, 1979), whereas an anisotropic "deviatoric" part is a dynamic part causing deformation and changes in shape. The lithosphere is considered to be composed of the elastic part of the crust and the viscous part of the upper mantle. Here we consider the entire lithosphere is floating on the asthenosphere and obeying the Navier-Stokes Equation:

$$
\rho \frac{D v}{D t}=-\nabla p+\nabla T+f
$$

where $\frac{D}{D t}(*)=\frac{d}{d t}(*)+* . \nabla(*), p$ is the pressure, $T$ is the stress tensor, $f=\rightarrow g$ is the downward force per unit volume and $v$ is the flow velocity. Flesch et al. (2001) assuming a specific viscous rheology and steady state, gave the following equation:

$$
\frac{\partial \sigma_{i j}}{\partial x_{j}}+\rho g \hat{z}_{i}=0
$$

where $\hat{\imath}$ is the unit vector in vertical direction, $\sigma_{i j}$ is the total stress and $x_{j}$ is the $j^{\text {th }}$ coordinate direction. In the above equation summation notation is used, where $i$ is given values of $x, y$, and $z$ and the repeated index $j$ is used to represent the summation over $x, y$, and $z$. Thus, the equation (1) takes the form: 


$$
\begin{aligned}
\frac{\partial \tau_{x x}}{\partial x}+\frac{\partial \sigma_{z z}}{\partial x}-\frac{\partial \tau_{z z}}{\partial x}+\frac{\partial \tau_{x y}}{\partial y}+\frac{\partial \tau_{x z}}{\partial z} & =0 \\
\frac{\partial \tau_{x y}}{\partial x}+\frac{\partial \sigma_{z z}}{\partial y}+\frac{\partial \tau_{y y}}{\partial y}-\frac{\partial \tau_{z z}}{\partial y}+\frac{\partial \tau_{y z}}{\partial z} & =0 \\
\frac{\partial \tau_{x z}}{\partial x}+\frac{\partial \tau_{y z}}{\partial y}+\frac{\partial \sigma_{z z}}{\partial z} & =-\rho g
\end{aligned}
$$

If the horizontal gradients in shear traction $\tau_{x y}$ and $\tau_{y z}$ are small compared to $\rho g$ i.e.,

$$
\frac{\partial \tau_{x z}}{\partial x}+\frac{\partial \tau_{y z}}{\partial y}<<\rho g
$$

then above equation can be expressed as

$$
\sigma_{z z}(z)=-\int_{-h}^{z} \rho\left(z^{\prime}\right) d z^{\prime}
$$

The vertically averaged equations $2(i)$ and $2(i i)$ from the surface at $z=-h$ to the base of the lithosphere at uniform depth $z=L$, where $h$ is the surface elevation and $L$ is the base of the lithosphere

$$
\begin{aligned}
& \frac{\partial \overline{\tau_{x x}}}{\partial x}-\frac{\partial \overline{\tau_{z z}}}{\partial x}+\frac{\partial \overline{\tau_{x y}}}{\partial y}=-\frac{\partial \overline{\sigma_{z z}}}{\partial x}-\frac{1}{L} \tau_{x z}(L) \\
& \frac{\partial \overline{\tau_{x y}}}{\partial x}-\frac{\partial \overline{\tau_{z z}}}{\partial y}+\frac{\partial \overline{\tau_{y y}}}{\partial y}=-\frac{\partial \overline{\sigma_{z z}}}{\partial y}-\frac{1}{L} \tau_{y z}(L)
\end{aligned}
$$

where $\tau_{x z}(L)$ and $\tau_{y z}(L)$ are the traction applied to the base of the lithosphere that fall out the vertical integrals $\left[\tau_{x z}(-h)\right.$ and $\tau_{y z}(-h)$ are zero $]$.

The vertically averaged stresses ${ }^{-} \tau_{i j}$ and ${ }^{-} \sigma_{z z}$ obtained by dividing the corresponding depth integrals by reference lithosphere thickness $L$ are defined as

$$
\begin{gathered}
\overline{\tau_{i j}}=\frac{1}{L} \int_{-h}^{L} \tau_{i j} d z \\
\overline{\sigma_{z z}}=-\frac{1}{L} \int_{-h}^{L}(L-z) \rho(z) g d z
\end{gathered}
$$


The vertically averaged vertical stress defined in equation (5) is equivalent to $1 / \mathrm{L}$ times the GPE per unit area defined by the reference level at the base of the lithosphere at depth $L$. The GPE per unit area of a column of material $U$ above at a given depth $z$ is given by the integral of the vertical stress $\sigma_{z z}$ from the $L$ to the surface $h$ (Molnar and Lyon-Caen, 1988):

$$
U=\int_{h}^{L} \sigma_{z z}\left(z^{\prime}\right) d z^{\prime}=\frac{g}{L} \int_{h}^{L} d z \int_{h}^{L} \rho\left(z^{\prime}\right) d z^{\prime}
$$

where $\rho(z)$ is the density, $L$ is the depth of the lithosphere, $h$ is the topography elevation and $g$ is the acceleration due to gravity. The horizontal stresses can be directly related to the vertical density distribution (Dahlen, 1981).

$$
\overline{\sigma_{x x}}=\frac{g}{L} \int_{h}^{L} \Delta \rho(z) d z
$$

where $\sigma_{x x}^{-}$is the horizontal stresses averaged over the thickness of the lithosphere, relative to a reference state against which the $\Delta \rho$ is measured. Using the definition of GPE in equation (6) the horizontal stress can be expressed in terms of the potential energies

$$
\sigma_{x x}=\frac{\Delta U}{L}
$$

where $\Delta U$ is the difference between the potential energy of the lithosphere column $U_{l}$ and the potential energy of some others reference column $U r$

$$
\Delta U=U_{l}-U_{r}
$$

We consider that in the Shillong plateau, the lithosphere has a uniform thickness of $100 \mathrm{~km}$, and beyond this depth there exist materials with almost uniform density. The GPE difference is estimated considering satellite altimetry data from Space Radar Topographic Mission (SRTM) and crustal thickness model CRUST 2.0 (Laske et al., 2001). We have considered the crustal and 
mantle densities $2750 \mathrm{~kg} / \mathrm{m}^{3}$ and $3300 \mathrm{~kg} / \mathrm{m}^{3}$, respectively as in CRUST 2.0 , and assumed that the lithosphere is Airy isostatically compensated. It means lesser crust density floats on a higher density mantle and forms the root due to topography, which provides lateral density contrast. This lateral density contrasts in the lithosphere produce the second order stress as deviatoric stress. We calculated GPE and its associated deviatoric stress field at each grid point $\left(0.25^{\circ} \mathrm{x}\right.$ $0.25^{\circ}$ grid spacing) using the formulation described above. Thus estimated GPE and deviatoric stress distribution are shown in Figs 9 and 10 respectively.

The estimated GPE values are found to vary in the range (1.47-1.58) $\times 10^{14} \mathrm{Nm}$ where the maximum value $1.58 \times 10^{14} \mathrm{Nm}$ corresponds to the highest location in Shillong plateau with an elevation $\sim 1722 \mathrm{~m}$. Vertically integrated horizontal deviatoric stresses in eastern and western edges of the plateau are $\sim 17 \times 10^{12} \mathrm{~N} / \mathrm{m}$ and $\sim 8 \times 10^{12} \mathrm{~N} / \mathrm{m}$, respectively and compressive in nature. The GPE derived deviatoric stresses may deviate from the actual values due to simplified two-dimensional approximations implicit in the thin sheet equation used to invert the GPE to stress. Further, no attempt is made either to estimate or to consider the dynamic topography component, which is sensitive to the viscous stresses as evident from recent GPS and MT studies (Bai et al., 2010; Copley et al., 2010; Clark, 2012).

\section{Discussion and Conclusions}

\subsection{Seismicity}

Two distinct trends of seismicity are identified in the Shillong plateau, one NNW trend in the western part of the plateau and one NNE trend in the eastern part of the plateau. We critically examined these two observed clusters of events (Fig. 6 a, b, c). A N-S cross section along A-A', 
across the western cluster zone, shows that the Dapsi thrust is the north dipping southern boundary of the seismic zone. It is, however, difficult to demarcate any south dipping northern boundary fault for the seismogenic zone as envisaged by Bilham and England (2001) in their pop-up tectonic model; the events also occur to the north of Oldham or Brahmaputra river fault (Fig. 6 a). It may be noted that most of the events occur by thrust/reverse or by strike slip mechanisms; only a few shallower $(<15 \mathrm{~km})$ earthquakes show normal faulting except one event (Event no. 90) at a depth $30 \mathrm{~km}$. According to Rao and Kumar (1997), the uplift of the plateau is facilitated by the Dauki fault to the south, Brahmaputra fault to the north, Dhubri fault to the west and Disang thrust to the east (Fig.1). However, in the pop-up tectonic model of Bilham and England (2001), it is argued that the Dauki fault is the southern boundary north dipping thrust fault and the Oldham fault is the northern boundary south dipping thrust fault. Later, Clark and Bilham (2008) has interpreted this pop-up due to a south verging ramp thrust, in which Oldham fault is caused by episodic slip on an antithetic fault in the hanging wall of this ramp. Biswas et al. (2007), on the other hand, proposed an inversion tectonics that developed on the passive continental margin. Formation of the Shillong plateau is thus debated by three possible processes: (a) pop up tectonics, (b) basement folding and (c) inversion tectonics and crustal tilting (Fig. 11). A few deeper (depth 40-60 km) earthquakes beneath the plateau are, however, difficult to explain with any tectonic model; deeper sub-crustal earthquakes in intraplate zone are still an enigma.

The cross section along B-B', through central part of the Shillong plateau, emphasizes that the earthquakes occur much north of the so called south dipping Oldham or Brahmaputra fault (Fig. 6b). This section also shows that the earthquakes are mostly confined within $40 \mathrm{~km}$ depth except 
one event (Event no. 74) at a depth of $60 \mathrm{~km}$. The events are of mostly thrust and strike slip mechanisms, except a few with normal faulting. Three normal faulting events occurred at shallower depth $(<15 \mathrm{~km})$ and two at 25-35 km depth. The section C-C' across the eastern part of the plateau includes mainly the events of cluster b (Fig. 6c). In this section the Sylhet fault earthquakes in the Bengal basin are also evident. All the events are of strike-slip mechanisms, and may be atrributed to the Sylhet fault in Bengal basin and to the Barapani shear fault zone in the Shillong plateau. All events are within a depth of $40 \mathrm{~km}$ except the event 1 at a depth $55 \mathrm{~km}$.

It may be noted that three events occurred in the central part of the Dauki fault where the hinge zone and the Dapsi thrust intersect the Dauki fault at the source zone of the 1923 large earthquake (Fig. 2). Two more events are recorded farther east where the Sylhet fault intersects the Dauki fault. The western part of the Dauki, on the other hand, is almost dormant, where the tectonic stress from the eastern Himalaya frontal system is mostly taken up by the north dipping seismogenic Dapsi thrust ( Kayal, 2001; Kayal et al., 2006 and 2012).

\subsection{Stress Pattern}

The stress inversion results shed a new light on the stress regime in the plateau and its implications to seismotectonics. Angelier and Baruah (2009) first attempted this study in NER, India. Using some 25 fault plane solutions, they reported a NNE-SSW compressive stress in the Shillong plateau. We have used 97 fault plane solutions in this analysis and observed that the tectonic stress regime of the western part of the plateau is different from that of the eastern part. The western part is dominated by NNW-SSE compressional stress $\left(\sigma_{1}\right)$ and ENE-WSW tensional stress $\left(\sigma_{3}\right)$, where the pop-up tectonic model is envisaged by Bilham and England 
(2001). The overall stress regime of the plateau is also dominated by the NNW-SSE compression (Fig. 7a). The NNW-SSE compression was attributed to back thrust from the Himalayas (e.g. Mukhopadhayay, 1984; Kayal and De,1991). Recent studies (e.g. Grujic et al., 2006; Biswas et al., 2007; Biswas and Grasemann, 2005), however, indicate that the tectonic development of the Shillong plateau did not influence the rock uplift rate in the Bhutan Himalaya. Further, Biswas e al. (2007) estimated $2^{\circ}-3^{\circ}$ northward tilting of the Shillong plateau, and suggested that a NNW-SSE compression in the Shillong plateau may be due to tectonic loading induced by crustal thickening of the Himalayas in the north. In a recent GPS survey, Jade et al. (2007) and Banerjee et al. (2008), however, reported southward motions 4-7 mm/yr at the sites in the Shillong plateau with respect to the IGS station in Lhasa (latitude: $29.657^{\circ} \mathrm{E}$, longitude: $91.104^{\circ} \mathrm{N}$ ) ; the reported displacement rates are with respect to the stable India.

The earthquakes in Shillong plateau occur in the upper lithosphere down to a depth of $60 \mathrm{~km}$, but no change in stress regime with depth is observed. Spatial variation of the stress is, however, evident within the plateau. The western part of the plateau is dominated by NNW-SSE compressional stress, while the eastern part by ENE-WSW compressional stress. No geologic correlation with fault(s) or fault intersections can be made with this spatial change in the stress regime. It is suggested that the western part of the plateau is more influenced by tectonic loading of the Himalayas and the eastern part by the Indo-Burma thrust.

\subsection{GPE derived stress}

Lateral density contrasts due to topography produce a second-order stress pattern with spatial wavelengths of 100-500 km (Heidbach et al., 2007). The Gravitational Potential Energy (GPE) 
associated stress has strong influence on the total stress field as reported for the central Andes ( 4000 m elevation) and Colorado ( 4200 m elevation) plateau (Flesch and Kreemer, 2010). In this study, we observe that due to higher topography and density heterogeneities, the western edge of the Shillong plateau shows a GPE variation with respect to that in the eastern edge.

Strain rate measured by the GPS measurements have not shown any E-W disparity in stress pattern in the Shillong plateau. Since the surface geophysical phenomena are intimately related to the geodynamical processes close to the Earth's surface; the estimated GPE may not adequately represent the stresses at deeper depth. The fault plane solution inversions, however, provide relative magnitude of principle stresses and heterogeneities with depth; no much change in stress pattern is observed at deeper depth down to $60 \mathrm{~km}$.

\section{ACKNOWLEDGEMENT}

We thank Dr. D. Ramaiah, Director, CSIR-North East Institute of Science and Technology (NEIST), Jorhat for his support and encouragement for carrying out this research. Prof. Andrew

J. Michael, USGS, USA and Prof. Jure Zalohar, University of Ljubljana, Solvenia are acknowledged for providing us the inversion code and for valuable suggestions. The authors are also thankful to Prof. J Gottsmann, Editor-in-Chief, Dr. Sebastiano D'Amico, Guest Editor and the two anonymous reviewers for their valuable comments and help. The Ministry of Earth Sciences, Government of India, New Delhi provides the financial support for this work. 


\section{References}

Allmendinger, R. W., Ramos, V. A., Jordan, T. E., Palma, M., and Isacks, B. L., 1983. Paleogeography and Andean structural geometry, northwest Argentina. Tectonics, 2, 1-16.

Angelier, J., 1975. Sur l'analyse de mrsures recueillies dans des sites failles: l'utilite d'une conformation entre les methods dynamiques et cinematiques. C. R. Acad. Sci. Paris, D., 284, $1805-1808$.

Angelier, J., 1984. Tectonic analysis of fault slip data sets. J. Geophys Res., 89, 5838-5848.

Angelier, J., 1989. From orientation to magnitudes in paleostress determination using fault slip data. J. Struct. Geol., 11 (1/2), 37-50.

Angelier, J., and Baruah, S., 2009. Seismotectonics in Northeast India: a stress analysis of focal mechanism solutions of earthquakes and its kinematic implications. Geophys. J. Int.,178, 303-326.

Bai, D., Unsworth, M. J., Meju, M. A., Ma, X., Teng, J., Kong, X., Sun, Y., Sun, J., Wang, L., Jiang, C., Zhao, C., Xiao, P., and Liu, M., 2010. Crustal deformation of the eastern Tibetan plateau revealed by magnetotelluric imaging. Nature Geoscience, doi: 10.1038/NGEO830.

Banerjee, P., Burgmann, R., Nagarajan, B., and Apel, E., 2008. Intraplate deformation of the Indian subcontinent. Geophys. Res. Lett., 35, doi:10.1029/2008GL035468.

Batchelor, G.K., 1967. An Introduction to Fluid Mechanics, Cambridge: Cambridge University Press.

Bhattacharya, P. M., Pujol, J., Mazumdar, R. K., and Kayal, J. R., 2005. Relocation of earthquakes in the Northeast India region using joint Hypocenter determination method. Curr. Sci., 89(8), 1404-1413.

Bhattacharya, P. M., Mukhopadhyay, S., Mazumdar, R. K., and Kayal J. R., 2008. 3-D seismic structure of the northeast India region and its implification for local and regional tectonics. Jour. Asian Earth Sci., 33, 25-41.

Biswas, S., and Grasemann, B., 2005. Quantitative morphotectonics of the southern Shillong Plateau (Bangladesh/India), Aust. J. Earth Sci., 97, 82 -93. 
Biswas, S., Coutand, I., Grujic, D., Hager, C., Sto“ckli , D. ,and Grasemann, B., 2007. Exhumation and uplift of the Shillong plateau and its influence on the eastern Himalayas: New constraints from apatite and zircon (U-Th-[Sm])/He and apatite fission track analyses. TECTONICS, VOL. 26, TC6013, doi:10.1029/2007TC002125.

Bilham, R., and England, P., 2001. Plateau 'pop up' in the great 1897 Assam earthquake. Nature, 410, 806-809.

BIS (Part 1), 2002. Indian standard criteria for earthquake resistant design of structures, Part 1 general provisions and buildings". Bureau of Indian Standards, New Delhi, 2002.

Bouchon, M., 1981. A simple method to calculate Green's functions for elastic layered media. Bull. Seism. Soc. Am., 71, 959-971.

Bucher, W. H., 1956. Role of gravity in orogenesis. Geol. Soc. Am. Bull., 67, 1295-1318.

Coutant, O., 1989. Program of Numerical Simulation AXITRA, Res. Report LGIT, Grenoble, in French.

Chen, W.P., and Molnar, P., 1983. Focal depths of intracontinental and intraplate earthquakes and their implications for the thermal and mechanical properties of the lithosphere. $J$. Geophys. Res., 88, 4183-4214.

Chen, W.P., and Molnar, P., 1990. Source parameters of earthquakes and intraplate deformation beneath the Shillong Plateau and northern Indo Burma ranges. J. Geophys. Res., 95, 12527-12552.

Clark, M.K., 2012. Continental collision slowing due to viscous mantle lithosphere rather than topography. Nature, $\mathbf{4 8 3 , 7 4 - 7 7 .}$

Clark, M., and Bilham, R., 2008. Moocene rise of the Shillong plateau and the beginning of the end for the Eastern Himalaya. Earth Planet. Sci. Lett., 269(3), 337-351, DOI: 10.1016/j.eps1.2008.01.045.

Copley, A., Avouac, J.P., Royer, J.Y., 2010. India-Asia collision and the Cenozoic slowdown of the Indian plate: Implications for the forces driving plate motions. J.Geophys.Res., 115, B03410, doi:10.1029/2009JB006634.

D’Amico, S., Orecchio, B., Presti, D., Zhu, L., Herrmann, R., B., and Neri, G., 2008. Moment tensor solutions in the area of the 1908 Messina earthquake: preliminary results. Miscellanea INGV, 8, 43-44. 
D’Amico, S., Orecchio, B., Presti, D., Zhu, L., Herrmann, R., B., and Neri, G., 2010. Broadband waveform inversion of moderate earthquakes in the Messina Straits, Southern Italy. Phys. Earth Planet. Int., 179, 97-106, doi: 10.1016/j.pepi.2010.01.012.

D’Amico, S., Orecchio, B., Presti, D., Gervasi, A., Zhu, L., Guerra, I., Neri, G., and Herrmann, R. B., 2011. Testing the stability of moment tensor solutions for small earthquakes in the Calabro-Peloritan Arc Region (southern Italy). Bollettino di Geofisica Teorica ed Applicata, 52, 283-298, doi: 10.4430/bgta0009.

Dahlen, F. A., 1981. Isostacy and the ambient state of stress in the oceanic lithosphere. $J$. Geophys. Res., 86, 7801-7807.

Dreger, D. S., 2003. TDMT_INV: Time domain seismic moment tensor inversion. In: Lee W. H. K., Kanamori, H., Jennings, P. C., and Kisslinger, C. (eds). International Handbook of Earthquake and Engineering Seismology, Vol. B, Academic Press, An Imprint of Elsevier Science, London, 1627 pp.

Dreger, D. S., and Helmberger, D. V., 1993. Determination of source parameters at regional distances with single station or sparse network data. J. Geophys Res., 98, 1162-1179.

Fan, G., and Wallace, T., 1991. The determination of source parameters for small earthquakes from a single, very broadband seismic station. Geophys. Res. Lett., 18, 1385-1388.

Flesch, L.M., Haines, A.J., and Holt, W.E., 2001. Dynamics of the India-Eurasia collision zone. J. Geophys. Res., 106, 16,435-16,460.

Flesch, L.M., and Kreemer, C., 2010. Gravitational potential energy and regional stress and strain rate fields for continental plateaus: Examples from the central Andes and Colorado Plateau. Tectonophysics, 482, 182-192.

Gowd, T. N., and Srirama Rao, S. V., 1992. Tectonic stress field in the Indian Subcontinent. Journal of Geophysicl Research, 97, No. B8, 11879-11888.

Grujic, D., Coutand, I., Bookhagen, B., Bonnet, S., Blythe, A., and Duncan, C., 2006. Climatic forcing of erosion, landscape and tectonics in the Bhutan Himalayas, Geology, 34, 801 - 804, doi:810.1130/G22648.22641.

Gupta, H. K., Singh, S. C., Dutta, T. K., and Saikia, M. M., 1984. Recent investigations of North East seismicity, Proc. International. Symp. Continental Seismicity and Earthquake Prediction. Go Gongxu and Ma Xing- Yuan Editors. Seismological Press. Beijing, pp. 63-71. 
Heidbach, O., Reinecker, J., Tingay, M., Müller, B., Sperner, B., Fuchs, K., and Wenzel, F., 2007. Plate boundary forces are not enough: Second- and third-order stress patterns highlighted in the World Stress Map database. Tectonics, 26, TC6014, doi:10.1029/2007TC002133.

Herrmann, R. B., 2002. An overview of synthetic seismogram computation, computer programs in Seismology. Saint Louis University, 183pp.

Herrmann, R. B., 2008. Towards automated focal mechanism and moment determination for the continental U. S.-an ANSS product. Final Technical Report USGS Grant 05HQGR0047, 16pp.

Herrmann, R. B., Withers, M., and Benz, H., 2008. The April 18, 2008 Illinois earthquake: an ANSS monitoring success. Seism. Res. Lett., 79, 830-843.

Hiller, K. and Elahi, M., 1988. Structural growth and hydrocarbon entrapment in the Surma basin, Bangladesh. In: Wagner, H.C.,Wagner, L.C., Wang, F.F.H., Wong, F.L. (Eds.), Petroleum Resources of China and Related Subjects, Houston, Texas. Circum-Pacific Council for Energy and Mineral Resources Earth Sci. Series, 10, 657-669.

Jade, S., Vijayan, M. S. M., Gupta, S. S., Kumar, P. D., Gaur, V. K., and Arumugam, S., 2007. Effect of the M 9.3 Sumatra-Andaman islands earthquake of 26 December 2004 at several permanent and campaign GPS stations in the Indian continent. International Journal Remote Sensing, 28(13-14), 3045-3054, doi:10.1080/01431160601094526.

Jaeger, J. C., Cook, N. G. W., 1979. Fundamental of rock mechanics, (3rd edn). Science Paperbacks, Chapman and Hall, London, 585.

Johnson, S. Y. and Alam, A. M. N., 1991. Sedimentation and Tectonics of the Sylhet Trough, Bangladesh, Geol. Soc. Am. Bull., 103, 1513-1527.

Kayal, J. R., 1987. Microseismicity and source mechanism study: Shillong plateau, northeast India. Bull. Seis. Soc. Am., 77, 184-194.

Kayal, J. R., 2001. Microearthquake activity in some path of the Himalaya and the tectonic Model. Tectonophysics, 339, 331-351.

Kayal, J. R., 2008. Microearthquake Seismology and Seismotectonics of South Asia, Heidelberg, Germany: Springer. 
Kayal, J. R., and De, R., 1991. Microseismicity and tectonics in North-east India. Bull. Seism. Soc. Am., 81, 131-138.

Kayal, J. R., Arefiev, S. S., Baruah, S., Hazarika, D., Gogoi, N., Kumar, A., Chowdhury, S. N., and Kalita, S., 2006. Shillong Plateau Earthquakes in northeast India region: Complex tectonic model. Curr. Sci., 91, 109-114.

Kayal, J. R., Arefiev, S. S., Baruah, S., Hazarika, D., Gogoi, N., Gautam, J. L., Baruah Santanu, Dorbath, C., Tatevossian, R., 2012. Large and great earthquakes in the Shillong plateau-Assam valley area of Northeast India region: Pop-up and transverse tectonics. Tectonophysics, 532-535, 186-192, DOI. 10.1016/j.tecto.2012.02.007.

Kikuchi, M., Kanamori, H., 1991. Inversion of complex body waves-III. Bull. Seismol. Soc. Am. 81, 2335-2350.

Kumar, M. R., Raju, P. S., Devi, E. U., Saul, J., and Ramesh, D. S., 2004. Crustal structure variations in northeast India from converted phases. Geophys. Res. Lett., 31, 1-4. DOI: 10.1029/2004GL020576.

Laske, G., Masters, G., and Reif, C., 2001. Crust 2.0, A new global crustal model at 2 x 2 degrees: http://mahi.ucsd.edu/Gabi/rem.html.2001.

Lienert, B. R., Berg, B. E., and Frazer, L. N., 1986. Hypocenter: An earthquake location method using centered, scaled and adaptively damped least squares. Bull. Seism. Soc. Am., 76, $771-783$.

Lohmann, H. H., 1995. On the tectonics of Bangladesh. Swiss Assoc. Pet. Geol. Eng. Bull., 62 (140), 29-48.

Mancilla, F., Ammon, C. J., Herrmann, R. B., 2002. Faulting parameters of the 1999 Mula earthquake, southern Spain. Tectonophysics, 354, 139-155.

Michael, A. J., 1984. Determination of stress from slip data: faults and folds. J. Geophys. Res., 89, 11517-26.

Michael, A. J., 1987. Stress rotation during the Coalinga aftershock sequence. J. Geophys. Res., 92, 7963-7979.

Mitra, S., Pristley, K., Bhattacharya, A., and Gaur, V. K., 2005. Crustal structure and earthquake focal depths beneath northeastern India and southern Tibet. Geophys. J. Int., 160, 227248. 
Molnar, P., 1987. The distribution of intensity associated with the great 1897 Assam earthquake and bounds on the extent of the rupture zone, J. Geol. Soc. India, 30, $13-27$.

Molnar, P., and Lyon-Caen, H., 1988. Some simple physical aspects of the support, structure and evolution of mountain belts. Spec. Pap. Geol. Soc. Am., 218, 179-207.

Mukhopadhyay, M., 1984. Seismotectonics of transverse lineaments in the eastern Himalaya and its foredeep. Tectonophysics, 109, 227-240.

Mukhopadhyay, S., Chander, R., and Khattri, K. N., 1993. Fine structure of seismotectonics in the western Shillong massif, northeastern India. Proc. Ind. Acad. Sci., 102, 383-398.

Mukhopadhyay, S., Chander, R., and Khattri, K. N., 1997. Crustal properties in the epicentral tract of the Great 1897 Assam Earthquake, northeastern India, Tectonophysics, 283, 311330.

Murthy, M. V. N., Talukdar, S. C., Bhattarcharya, A. C. and Chakrabarti, C., 1969. The Dauki fault of Assam, Bull. O.N.G.C., 6 (2), 57-64.

Murphy, R.W., 1988. Staff of BOGMC, 1988. Bangladesh enters the oil era. Oil Gas J., $76-82$.

Musumeci, C., Patane, D., Scarfi, L., and Gresta, S., 2005. Stress Direction and Shear-Wave Anisotropy: Observations from Local Earthquakes in Southeastern Sicily, Italy. Bull. Seism. Soc. Am, 95, 1359-1374.

Nandy, D. R., and Dasgupta, S., 1991. Seismotectonic domains of Northeastern India and adjacent areas: Geology and geodynamics of Himalayan collision zone, pt.2. Physics and Chemistry of Earth, 18( No. 1-11) Pergamon press, PLC. Oxford, 371-384.

Nandy, D. R., 2001. Geodynamics of Northeastern India and the adjoining region, $A C B$ publications, Calcutta.

Ni, J. F., Guzman-Speziale, M., Bevis, M., Holt, W. E., Wallace, T. C., and Seager, W. R. 1989. Accretionary tectonics of Burma and the three-dimensional geometry of the Burma subduction zone. Geology, 17, 68-71.

Oldham, R. D., 1899. Report on the great earthquake of 12th June, 1897. Geol. Surv. Ind. Mem., 29, 1-379.

Parvez, I. A., Vaccari, F., and Panza, G. F., 2003. A deterministic seismic hazard map of India and adjacent areas. Geophys. J. Int., 155, 489-508. 
Rajendran, K., Talwani, P., and Gupta, H. K., 1992. State of stress in the Indian Subcontinent: A review. Current Science, 62, 86-93.

Rao, N. P., and Kumar, M. R., 1997. Uplift and tectonics of the Shillong Plateau, Northeast India. Jour. Phys. Earth, 45, 167-176.

Ristau, J., Rogers, G. C., and Cassidy, J. F., 2003. Moment magnitude-Local magnitude calibration for earthquakes off Canada's west Coast. Bull. Seism. Soc. Am., 93, 22962300.

Ristau, J., Rogers, G. C., and Cassidy, J. F., 2005. Moment magnitude-Local magnitude calibration for earthquakes in Western Canada. Bull. Seism. Soc. Am., 95, 1994-2000.

Scarfi, L., Langer, H., and Gresta, S., 2003. High-precession relative locations of two microearthquakes clusters in southeastern Sicily, Italy. Bull. Seism. Soc. Am., 93, 1479-1497.

Szeliga, W., Martin, S., Hough, S., Bilham, R., 2010. Intensity, magnitude, location and attenuation in India for felt earthquakes since 1762. Bull. Seism Soc Am. 100 (2), 570584

Shamsuddin, A. K. M., and S. K. M. Abdullah (1997), Geologic evolution of the Bengal Basin and its implication in hydrocarbon exploration in Bangladesh, Indian J. Geol., 69(2), 93 $-121$.

Tandon, A.N., 1954. A study of Assam earthquake of August 1950 and its aftershocks. Indian J. Meteorol. Geophys., 5, 95-137.

Tan, Y., Zhu, L., Helmberger, D., and Uhrhammer, R., 2006. Locating and modeling regional earthquakes with two stations. J. Geophys. Res., 111, B01306, 15pp.

Verma, R. K., Mukhopadhyay, M., and Ahluwalia, M. S., 1976. Seismicity, gravity and tectonics of Northeast India and Northern Burma. Bull. Seism. Soc., 66, 1683-1694.

Yin, A., Dubey, C. S., Webb,A. A. G., Kelty, T. K., Grove, M., Gehrels, G. E., and Burgess, W. P. (2010). Geologic correlation of the Himalayan orogen and Indian craton: Part 1. Structural geology, U-Pb zircon geochronology, and tectonic evolution of the Shillong Plateau and its neighboring regions in NE India, Geological Society of America Bulletin, 122;336-359, doi: 10.1130/B26460.1.

Zalohar, J., and Vrabec, M., 2007. Paleostress analysis of heteroge-neous fault-slip data: The Gauss Method. J. Struct. Geol., 29, 1798-1810. 
Zahradník, J., Janskí, J., and Papatsimpa, K., 2001. Focal mechanisms of weak earthquakes from amplitude spectra and polarities. Pure Appl. Geophys., 158, 647-665.

Zahradnik, J., Serpetsidaki, A., Sokos, E., and Tselentis, G. A., 2005. Iterative deconvolution of regional waveforms and double-event interpretation of the 2003 Lefkada earthquake, Greece. Bull. Seism. Soc. Am., 95, 159-172.

Zhu, L., Akyol, N., Mitchell, B., and Sozbiliz, H., 2006. Seismotectonics of western Turkey from high resolution earthquake relocations and moment tensor determinations. Geophys. Res. Lett., 33, L07316, 4pp.

Zoback, M.L., and Zoback, M. D., 1980. State of stress in the conterminous United States. J. Geophys. Res., 85, 6113-6156.

\section{Figure Captions:}

Figure 1. Map showing major tectonic features of northeast India region (after Kayal et al., 2006). Two great earthquakes $(M>8.0)$ are shown by stars, and the large earthquakes $(M>7.0)$ by circles; the year of occurrences is annotated. The digital seismic stations are shown by green triangles. The model fault plane solution of the 1897 great earthquake is shown (after Bilham and England, 2001). The major tectonic features in the region are indicated; MCT: Main Central Thrust, MBT: Main Boundary Thrust, DF: Dauki Fault, DT: Dapsi Thrust, OF: Oldham Fault, CF: Chedrang Fault, BS: Barapani Shear Zone, KF: Kopili Fault, NT: Naga Thrust, DsT: Disang Thrust, EBT: Eastern Boundary Thrust, Brhm. R.: Brahmaputra River, SP: Shillong Plateau and MH: Mikir Hills. Inset: Map of India showing study region.

Figure 2. Map showing epicenters of 97 earthquakes used in this study. Solid circles indicate the events of published fault plane solutions, open circles the events of waveform inversion solution in this study. Tectonic features are same as in Figure 1. Two clusters ' $a$ ' and 'b' are shown. A-A', 
B-B' and $\mathrm{C}-\mathrm{C}^{\prime}$ are three longitude bins along which depth sections are shown in Figure 6 (a), (b) and (c).

Figure 3. Map showing fault plane solutions of 97 earthquakes in the Shillong plateau; tectonic features as in Figure 1.

Figure 4. Sensitivity of fault plane solutions tested with three published velocity models (as referred). The velocity model of Bhattacharya et al. (2005) gives the best results for waveform inversion. DC\% stands for Double Couple percentage.

Figure 5(a). Waveform inversion for the event 35 (Table 1); a comparison of synthetic (red curve) and observed (black curve) waveforms at stations NGL, JPA, TZR and RPA for the preferred fault plane solution. $\mathrm{X}$-axis indicates time in sec and $\mathrm{Y}$-axis amplitude in meter. Maximum amplitudes are shown at traces. The inversion results gives strike $126^{\circ}$, dip $81^{\circ}$, rake $176^{\circ}$ and $\mathrm{Mw} 3.6$ for the event.

Figure 5(b). Waveform inversion for the event 49 (Table 1) using data from six stations: GAU, NGL, JPA, TZR, RPA and AZL. The inversion results gives strike $230^{\circ}$, dip $29^{\circ}$, rake $144^{\circ}$ and Mw 3.8 for the event. Other descriptions are same as Figure 5(a).

Figure 6(a). Depth section of the earthquakes along A-A (Figure 2); type of solutions are annotated (S: strike slip, T: Thrust, N: Normal). Tectonic features are marked; descriptions as in Figure 1.

Figure 6(b). Depth section of the events along B-B' (Figure 2).. Other descriptions as in Figure $6 a$. 
Figure 6(c). Depth section of the earthquakes along C-C' (Figure 2). Other descriptions as in Figure 6a.

Figure 7. Stress tensor inversion results: (a) Shillong plateau, (b) Cluster ' $a$ ' and ' $b$ ' and (c) for depth $\leq 30 \mathrm{~km}$ and $>30 \mathrm{~km} . \mathrm{G}$ and $\mathrm{M}$ denotes the Gauss method and Michael method, respectively. Convergent arrows indicate the direction of maximum principal stress and the divergent arrows indicate the direction of least principal stress in Gauss method. 1, 2 and 3 indicate the maximum, intermediate and least principal axes respectively in Michael method. The 95\% confidence limits are shown by closed contour.

Figure 8. Probability density function of rotation of the compressional stress axis, the clusters ' $b$ ' and ' $a$ '. The vertical axis is the percentage probability that the rotation is within $0.5^{\circ}$ of the point on the horizontal axis.

Figure 9. GPE estimated from SRTM 30 and Crust 2.0 model for the Shillong plateau region. The contour interval are at $0.01 \times 10^{14} \mathrm{Nm}$.

Figure 10. The GPE derived deviatoric stress in the Shillong plateau region. The red arrows in the circles represent the stress pattern corresponding to the clusters "a" and "b" (Fig. 2). The direction of compressive stress in the eastern edge of the plateau is approximately in NE direction while in western edge in NW direction.

Figure 11. N-S cross section at $91^{\circ} 40^{\prime} \mathrm{E} \pm 10^{\prime}$ after Biswas et al. (2007). The thickness of the sediments in the Sylhet trough is based on work by Shamsuddin and Abdullah (1997). Position and attitude of the Dauki and Oldham faults are after Bilham and England (2001). The position 
of the Moho (white boxes) is based on data from Mitra et al. (2005). Light brown bars in the yellow zone correspond to the maximum thickness of the sedimentary cover deduced from thermal modeling of AFT data (Apatite and Zircon (U-Th-[Sm])/He) by Biswas et al. (2007). Dashed lines indicate the minimum thickness estimate. The units of different rates are in $\mathrm{mm} / \mathrm{a}$ (Biswas et al., 2007). 
Tables:

Table 1. List of earthquakes used in this study.

\begin{tabular}{|c|c|c|c|c|c|c|c|}
\hline NO. & DATE & $\begin{array}{l}\text { LONG } \\
\left({ }^{\circ} \mathrm{E}\right)\end{array}$ & $\begin{array}{l}\text { LAT } \\
\left({ }^{\circ} \mathrm{N}\right)\end{array}$ & $\begin{array}{l}\text { DEPTH } \\
(\mathrm{km})\end{array}$ & $\begin{array}{l}\text { MAG } \\
M w\end{array}$ & $\begin{array}{l}\text { Type of } \\
\text { faulting }\end{array}$ & Reference \\
\hline 1 & 19630619 & 92.06 & 24.97 & 52 & & Thrust & Chen and Molnar (1990) \\
\hline 2 & 19630621 & 92.09 & 25.13 & $38+/-4$ & & Thrust & Chen and Molnar (1990) \\
\hline 3 & 19680612 & 91.94 & 24.83 & 41 & $M=5.3$ & Thrust & Chen and Molnar (1990) \\
\hline 4 & 19680818 & 90.62 & 26.42 & $29+/-3$ & $M=5.1$ & Thrust & Chen and Molnar (1990) \\
\hline 5 & 19710717 & 93.15 & 26.41 & 36 & & Thrust & Chen and Molnar (1990) \\
\hline 6 & 19700725 & 88.55 & 25.72 & 33 & $\mathrm{mb}=5.2$ & Thrust & Nandy (2001) \\
\hline 7 & 1982 & 91.75 & 25.65 & $<40$ & & Thrust & Kayal (1987) \\
\hline 8 & 19820705 & 90.3 & 25.91 & 13 & 5 & Strike-slip & Angelier and Baruah (2009) \\
\hline 9 & 19820831 & 91.5 & 25.38 & 33 & 5 & Thrust & Angelier and Baruah (2009) \\
\hline 10 & 1984 & 90.85 & 25.75 & $<40$ & & Thrust & Kayal (1987) \\
\hline 11 & 1984 & 91 & 25.5 & & & Thrust & Mukhopadhay et al. (1993) \\
\hline 12 & 1984 & 90.75 & 25.55 & & & Thrust & Mukhopadhay et al. (1993) \\
\hline 13 & 1984 & 90.75 & 25.85 & & & Strike-slip & Mukhopadhay et al. (1993) \\
\hline 14 & 1984 & 91.15 & 25.7 & & & Strike-slip & Mukhopadhay et al. (1993) \\
\hline 15 & 19840922 & 92.15 & 26.49 & 29 & $m s=5$ & Strike-slip & Nandy and Dasgupta (1991) \\
\hline 16 & 19860219 & 91.13 & 25.1 & 18 & 5.2 & Thrust & Angelier and Baruah (2009) \\
\hline 17 & 19880206 & 91.52 & 24.65 & $31+/-3$ & 5.8 & Strike-slip & Chen and Molnar (1990) \\
\hline 18 & 19921022 & 91.74 & 25.46 & 22 & 4.6 & Thrust & Angelier and Baruah (2009) \\
\hline 19 & 19921029 & 92.04 & 25.31 & 43 & 5.2 & Strike-slip & Angelier and Baruah (2009) \\
\hline 20 & 19970508 & 92.23 & 25 & 30 & 5 & Strike-slip & Angelier and Baruah (2009) \\
\hline 21 & 19991005 & 91.89 & 25.88 & 33 & 5.2 & Strike-slip & Global CMT Catalog \\
\hline 22 & 20010215 & 92.59 & 26.68 & 44 & 4 & Thrust & Kayal et al. (2012) \\
\hline 23 & 20010227 & 90.73 & 26.14 & 17 & 4.3 & Thrust & Angelier and Baruah (2009) \\
\hline 24 & 20010311 & 91.73 & 25.81 & 15.2 & 3.77 & Thrust & This study \\
\hline 25 & 20010406 & 92.76 & 26.53 & 48 & 3.7 & Thrust & Kayal et al. (2012) \\
\hline 26 & 20011119 & 91.06 & 25.82 & 10.18 & 3.57 & Strike-slip & This study \\
\hline 27 & 20011125 & 91.37 & 25.98 & 12 & 3.6 & Strike-slip & This study \\
\hline 28 & 20111212 & 91.2 & 25.14 & 14 & 3.6 & Strike-slip & This study \\
\hline 29 & 20020906 & 91.71 & 25.62 & 29.4 & 3.5 & Strike-slip & This study \\
\hline 30 & 20020924 & 90.38 & 25.92 & 19.64 & 3.5 & Strike-slip & This study \\
\hline 31 & 20021001 & 90.34 & 25.93 & 49.67 & 3.5 & Strike-slip & This study \\
\hline 32 & 20021012 & 92.95 & 25.37 & 29.5 & 4 & Strike-slip & Kayal et al. (2012) \\
\hline 33 & 20021014 & 91.33 & 25.08 & 36.95 & 3.8 & Normal & This study \\
\hline 34 & 20021115 & 91.43 & 26.22 & 41.94 & 3.4 & Thrust & This study \\
\hline 35 & 20021116 & 90.78 & 25.78 & 10.19 & 3.8 & Normal & This study \\
\hline 36 & 20021229 & 89.18 & 26.17 & 5.25 & 3.6 & Strike-slip & This study \\
\hline 37 & 20021229 & 88.91 & 26.35 & 29.47 & 3.7 & Normal & This study \\
\hline 38 & 20030104 & 92.59 & 25.86 & 23 & 3.9 & Strike-slip & Kayal et al. (2012) \\
\hline 39 & 20030105 & 89.96 & 26.49 & 22.36 & 3.6 & Strike-slip & This study \\
\hline 40 & 20030115 & 93.11 & 25.94 & 23.5 & 3.7 & Normal & Kayal et al. (2012) \\
\hline
\end{tabular}




\begin{tabular}{|c|c|c|c|c|c|c|c|}
\hline 41 & 20030125 & 92.32 & 24.96 & 48 & 3.8 & Nrmal & Kayal et al. (2012) \\
\hline 42 & 20030204 & 90.3 & 25.87 & 21.27 & 3.5 & Strike-slip & This study \\
\hline 43 & 20030215 & 90.39 & 25.96 & 36.63 & 4.3 & Strike-slip & This study \\
\hline 44 & 20030220 & 91.02 & 25.72 & 43 & 3.8 & Strike-slip & This study \\
\hline 45 & 20030317 & 90.65 & 26.26 & 6.62 & 3.6 & Normal & This study \\
\hline 46 & 20030317 & 90.46 & 26.57 & 37.17 & 3.6 & Thrust & This study \\
\hline 47 & 20030401 & 91.59 & 25.76 & 14 & 3.4 & Thrust & Angelier and Baruah [2009] \\
\hline 48 & 20030401 & 91.49 & 25.64 & 41.78 & 3.5 & Strike-slip & This study \\
\hline 49 & 20030412 & 90.75 & 26.33 & 18.3 & 3.8 & Thrust & This study \\
\hline 50 & 20030511 & 92.85 & 26.29 & 53.2 & 3.8 & Strike-slip & Kayal et al. (2012) \\
\hline 51 & 20030609 & 90.73 & 25.97 & 11.09 & 3.6 & Thrust & This study \\
\hline 52 & 20030626 & 90.01 & 26.38 & 24.9 & 3.56 & Strike-slip & This study \\
\hline 53 & 20030714 & 91.54 & 25.59 & 13.6 & 3.4 & Strike-slip & This study \\
\hline 54 & 20030717 & 90.68 & 25.54 & 20.8 & 4.1 & Thrust & Kayal et al. (2012) \\
\hline 55 & 20030723 & 90.39 & 26.38 & 21.27 & 3.82 & Strike-slip & This study \\
\hline 56 & 20030730 & 91.6 & 25.27 & 24.66 & 3.49 & Thrust & This study \\
\hline 57 & 20030823 & 90.6 & 25.53 & 14 & 2.5 & Thrust & Angelier and Baruah (2009) \\
\hline 58 & 20030823 & 90.61 & 25.96 & 5 & 2.5 & Thrust & Angelier and Baruah (2009) \\
\hline 59 & 20030929 & 91.63 & 25.62 & 6 & 2.5 & Strike-slip & Angelier and Baruah (2009) \\
\hline 60 & 20030930 & 90.08 & 25.66 & 26 & 2.5 & Strike-slip & Angelier and Baruah (2009) \\
\hline 61 & 20031001 & 90.01 & 26.28 & 24 & 3.2 & Thrust & Angelier and Baruah (2009) \\
\hline 62 & 20031002 & 90.88 & 26.13 & 20 & 2.6 & Strike-slip & Angelier and Baruah (2009) \\
\hline 63 & 20031002 & 89.8 & 25.46 & 19.19 & 3.7 & Thrust & This study \\
\hline 64 & 20031003 & 90.54 & 25.75 & 16 & 2.5 & Strike-slip & Angelier and Baruah (2009) \\
\hline 65 & 20031005 & 90.68 & 25.77 & 11 & 2.5 & Strike-slip & Angelier and Baruah (2009) \\
\hline 66 & 20031109 & 90.81 & 25.54 & 21.55 & 3.5 & Strike-slip & This study \\
\hline 67 & 20031112 & 90.99 & 25.65 & 12 & 2.5 & Strike-slip & Angelier and Baruah (2009) \\
\hline 68 & 20031119 & 92.19 & 26.15 & 35.14 & 3.57 & Strike-slip & This study \\
\hline 69 & 20031206 & 90.51 & 25.93 & 15.1 & 3.5 & Normal & This study \\
\hline 70 & 20031215 & 92.05 & 26.43 & 33.8 & 3.52 & Strike-slip & This study \\
\hline 71 & 20040120 & 91.84 & 25.56 & 41 & 3.7 & Normal & Angelier and Baruah (2009) \\
\hline 72 & 20040120 & 91.79 & 25.56 & 43.3 & 3.65 & Thrust & This study \\
\hline 73 & 20040124 & 91.42 & 25.58 & 52.5 & 3.8 & Thrust & Kayal et al. (2012) \\
\hline 74 & 20040128 & 91.08 & 25.31 & 62 & 3.6 & Thrust & Angelier and Baruah (2009) \\
\hline 75 & 20040604 & 90.57 & 25.61 & 49.91 & 3.61 & Thrust & This study \\
\hline 76 & 20040604 & 90.8 & 25.86 & 12 & 5.3 & Normal & Angelier and Baruah (2009) \\
\hline 77 & 20040607 & 92.24 & 25.98 & 15 & 5 & Thrust & Angelier and Baruah (2009) \\
\hline 78 & 20040804 & 90.52 & 25.97 & 19.4 & 4.2 & Normal & Kayal et al. (2012) \\
\hline 79 & 20041102 & 92.22 & 25.49 & 25 & 4.2 & Thrust & Kayal et al. (2012) \\
\hline 80 & 20041209 & 92.47 & 24.89 & 43.7 & 4 & Strike-slip & Kayal et al. (2012) \\
\hline 81 & 20050131 & 91.99 & 26.73 & 44.29 & 3.51 & Normal & This study \\
\hline 82 & 20090404 & 90.62 & 26.05 & 17.94 & 2.66 & Strike-slip & This study \\
\hline 83 & 20090404 & 90.52 & 26.19 & 23.35 & 2.78 & Thrust & This study \\
\hline 84 & 20090404 & 90.57 & 26.06 & 8.6 & 3.8 & Strike-slip & Kayal et al. (2012) \\
\hline 85 & 20090407 & 90.78 & 25.9 & 33.1 & 3.16 & Thrust & This study \\
\hline 86 & 20090410 & 90.29 & 25.9 & 22.38 & 3.08 & Normal & This study \\
\hline
\end{tabular}




$\begin{array}{lllrllll}87 & 20090412 & 90.81 & 25.83 & 20.96 & 3.06 & \text { Thrust } & \text { This study } \\ 88 & 20090704 & 90.78 & 25.9 & 33.1 & 3.16 & \text { Thrust } & \text { This study } \\ 89 & 20090726 & 90.72 & 26.03 & 18.93 & 3.3 & \text { Thrust } & \text { This study } \\ 90 & 20090731 & 90.92 & 26.08 & 28.05 & 3.24 & \text { Normal } & \text { This study } \\ 91 & 20090804 & 90.62 & 26.05 & 17.94 & 2.66 & \text { Strike-slip } & \text { This study } \\ 92 & 20090807 & 90.63 & 25.79 & 8.55 & 2.52 & \text { Strike-slip } & \text { This study } \\ 93 & 20090814 & 90.19 & 25.91 & 22.67 & 3.41 & \text { Strike-slip } & \text { This study } \\ 94 & 20090814 & 91.41 & 25.3 & 24.16 & 3.43 & \text { Normal } & \text { This study } \\ 95 & 20090819 & 92.38 & 26.67 & 10 & 4.9 & \text { Normal } & \text { Kayal et al. (2012) } \\ 96 & 20090819 & 92.3 & 26.49 & 10 & 5.1 & \text { Strike-slip } & \text { Kayal et al. (2012) } \\ 97 & 20090908 & 90.67 & 25.9 & 7.12 & 3.45 & \text { Strike-slip } & \text { This study }\end{array}$


Table 2. Results of Stress Tensor Inversion for Shillong Plateau of NER, India using Michael's

and Gauss method.

\begin{tabular}{|c|c|c|c|c|c|c|c|c|c|c|}
\hline \multirow[t]{2}{*}{ Method } & \multicolumn{2}{|c|}{$\left(\sigma_{1}\right)$} & \multicolumn{2}{|c|}{$\left(\sigma_{2}\right)$} & \multicolumn{2}{|c|}{$\left(\sigma_{3}\right)$} & \multirow{2}{*}{$\phi$} & \multirow{2}{*}{$\begin{array}{l}\text { Av. } \\
\text { Misfit }\end{array}$} & \multirow{2}{*}{ Variance } & \multirow[b]{2}{*}{$\begin{array}{l}\text { St. } \\
\text { Dev }\end{array}$} \\
\hline & Azimuth & Plunge & Azimuth & Plunge & Azimuth & Plunge & & & & \\
\hline Michael & $166^{\circ}$ & $12^{\circ}$ & $74^{\circ}$ & $9^{\circ}$ & $310^{\circ}$ & $74^{\circ}$ & 0.2 & $9.1^{\circ}$ & 0.12 & 0.08 \\
\hline Gauss & $164^{\circ}$ & $23^{\circ}$ & $64^{\circ}$ & $22^{\circ}$ & $295^{\circ}$ & $57^{\circ}$ & 0.2 & $8^{\circ}$ & ----- & ----- \\
\hline
\end{tabular}

Note: $\sigma_{1}, \sigma_{2}, \sigma_{3}=$ Principal, Intermediate and Least Principal axis, St. Dev.= Standard deviation.

$\phi$, the ratio of principal stress differences as defined by Angelier $(1975,1989)$, $\phi=\left(\sigma_{2}-\sigma_{3}\right) /\left(\sigma_{1}-\sigma_{3}\right)$. 
Table 3. Results of Stress Tensor Inversion for the clusters of events.

\begin{tabular}{|c|c|c|c|c|c|c|c|c|c|c|c|}
\hline \multirow{2}{*}{$\begin{array}{l}\text { Cluste } \\
\mathrm{r}\end{array}$} & \multirow{2}{*}{ Method } & \multicolumn{2}{|c|}{$\left(\sigma_{1}\right)$} & \multicolumn{2}{|l|}{$\left(\sigma_{2}\right)$} & \multicolumn{2}{|c|}{$\left(\sigma_{3}\right)$} & \multirow[t]{2}{*}{$\phi$} & \multirow{2}{*}{$\begin{array}{l}\text { Av. } \\
\text { Misfi } \\
\text { t }\end{array}$} & \multirow{2}{*}{$\begin{array}{l}\text { Varianc } \\
\text { e }\end{array}$} & \multirow{2}{*}{$\begin{array}{l}\text { St. } \\
\text { Dev }\end{array}$} \\
\hline & & $\begin{array}{l}\text { Azimut } \\
\mathrm{h}\end{array}$ & $\begin{array}{l}\text { Plung } \\
\mathrm{e}\end{array}$ & $\begin{array}{l}\text { Azimut } \\
\mathrm{h}\end{array}$ & $\begin{array}{l}\text { Plung } \\
\mathrm{e}\end{array}$ & $\begin{array}{l}\text { Azimut } \\
\mathrm{h}\end{array}$ & $\begin{array}{l}\text { Plung } \\
\mathrm{e}\end{array}$ & & & & \\
\hline \multirow[t]{2}{*}{$\mathrm{a}$} & $\begin{array}{l}\text { Michae } \\
1\end{array}$ & $158^{\circ}$ & $13^{\circ}$ & $64^{\circ}$ & $15^{\circ}$ & $289^{\circ}$ & $69^{\circ}$ & $\begin{array}{l}0 . \\
2\end{array}$ & $8.2^{\circ}$ & 0.3 & 0.06 \\
\hline & Gauss & $170^{\circ}$ & $12^{\circ}$ & $77^{\circ}$ & $12^{\circ}$ & $305^{\circ}$ & $73^{\circ}$ & $\begin{array}{l}0 . \\
3\end{array}$ & $8^{\circ}$ & ---- & ---- \\
\hline \multirow[t]{2}{*}{$\mathrm{b}$} & $\begin{array}{l}\text { Michae } \\
1\end{array}$ & $204^{\circ}$ & $10^{\circ}$ & $111^{\circ}$ & $8^{\circ}$ & $346^{\circ}$ & $76^{\circ}$ & $\begin{array}{l}0 . \\
5\end{array}$ & $8.1^{\circ}$ & 0.2 & 0.16 \\
\hline & Gauss & $212^{\circ}$ & $13^{\circ}$ & $307^{\circ}$ & $23^{\circ}$ & $96^{\circ}$ & $63^{\circ}$ & $\begin{array}{l}0 . \\
2\end{array}$ & $9^{\circ}$ & ---- & ---- \\
\hline
\end{tabular}


Table 4. Results of Stress Tensor Inversion at two different depth ranges.

\begin{tabular}{|c|c|c|c|c|c|c|c|c|c|c|c|}
\hline \multirow{2}{*}{$\begin{array}{l}\text { Dept } \\
\mathrm{h} \\
(\mathrm{km})\end{array}$} & \multirow{2}{*}{ Method } & \multicolumn{2}{|c|}{$\left(\sigma_{1}\right)$} & \multicolumn{2}{|c|}{$\left(\sigma_{2}\right)$} & \multicolumn{2}{|c|}{$\left(\sigma_{3}\right)$} & \multirow[b]{2}{*}{$\phi$} & \multirow{2}{*}{$\begin{array}{l}\text { Av. } \\
\text { Misfi } \\
t\end{array}$} & \multirow{2}{*}{$\begin{array}{l}\text { Varianc } \\
\mathrm{e}\end{array}$} & \multirow{2}{*}{$\begin{array}{l}\text { St. } \\
\text { Dev. }\end{array}$} \\
\hline & & $\begin{array}{l}\text { Azimut } \\
\mathrm{h}\end{array}$ & $\begin{array}{l}\text { Plung } \\
\mathrm{e}\end{array}$ & $\begin{array}{l}\text { Azimut } \\
\mathrm{h}\end{array}$ & $\begin{array}{l}\text { Plung } \\
\mathrm{e}\end{array}$ & $\begin{array}{l}\text { Azimut } \\
\mathrm{h}\end{array}$ & $\begin{array}{l}\text { Plung } \\
\mathrm{e}\end{array}$ & & & & \\
\hline \multirow[t]{2}{*}{$0-30$} & $\begin{array}{l}\text { Michae } \\
1\end{array}$ & $176^{\circ}$ & $12^{\circ}$ & $272^{\circ}$ & $22^{\circ}$ & $58^{\circ}$ & $64^{\circ}$ & $\begin{array}{l}0 . \\
5\end{array}$ & $7.3^{\circ}$ & 0.3 & 0.06 \\
\hline & Gauss & $164^{\circ}$ & $23^{\circ}$ & $64^{\circ}$ & $22^{\circ}$ & $295^{\circ}$ & $57^{\circ}$ & $\begin{array}{l}0 . \\
2\end{array}$ & $8^{\circ}$ & ---- & ----- \\
\hline \multirow[t]{2}{*}{$>30$} & $\begin{array}{l}\text { Michae } \\
1\end{array}$ & $172^{\circ}$ & $17^{\circ}$ & $77^{\circ}$ & $13^{\circ}$ & $313^{\circ}$ & $67^{\circ}$ & $\begin{array}{l}0 . \\
5\end{array}$ & $6.5^{\circ}$ & 0.2 & 0.16 \\
\hline & Gauss & $162^{\circ}$ & $2^{\circ}$ & $71^{\circ}$ & $24^{\circ}$ & $257^{\circ}$ & $66^{\circ}$ & $\begin{array}{l}0 . \\
1\end{array}$ & $8^{\circ}$ & ---- & $\begin{array}{l}---- \\
-\end{array}$ \\
\hline
\end{tabular}




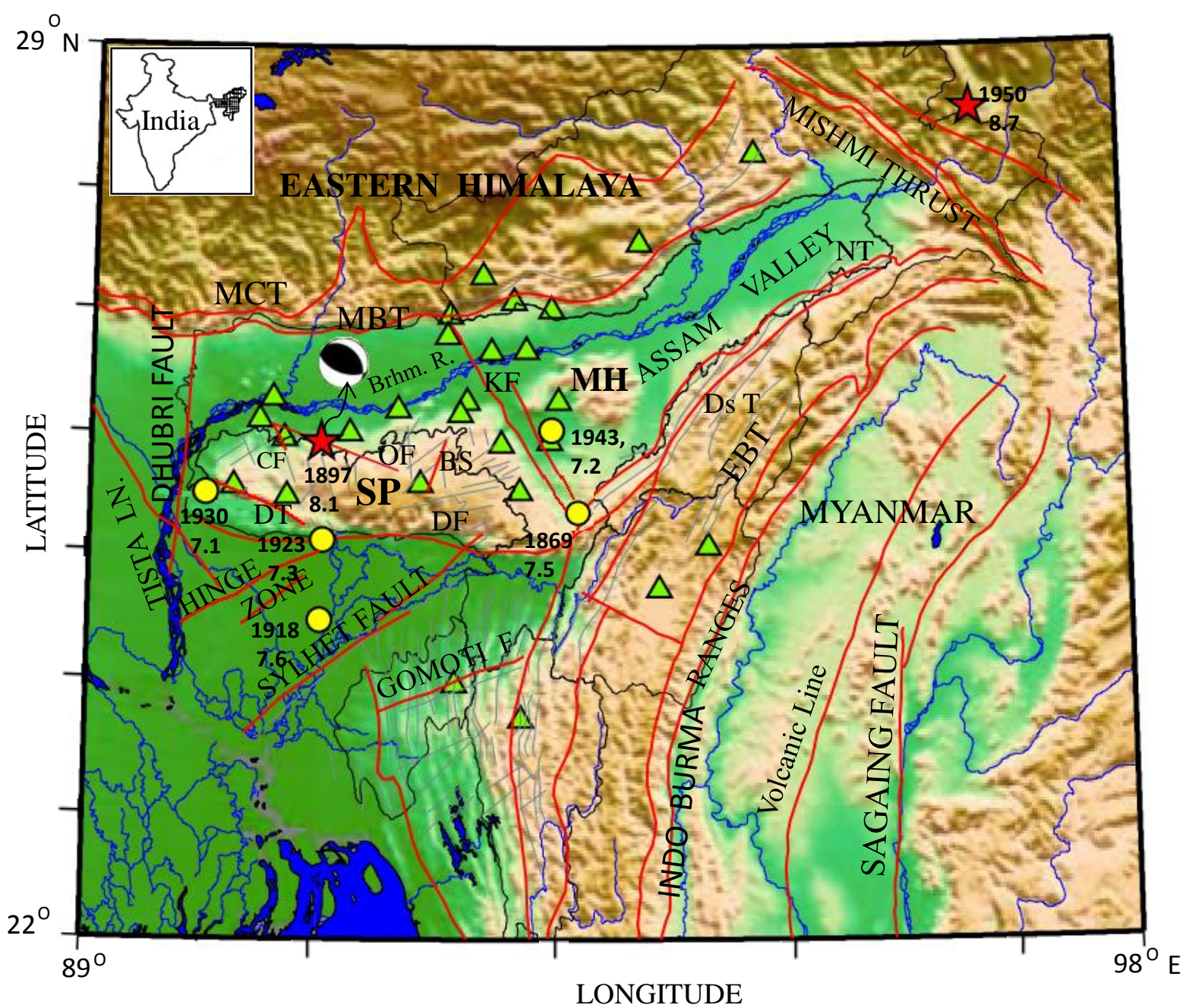

Figure 1. Map showing major tectonic features of northeast India region (after Kayal et al., 2006). Two great earthquakes $(M>8.0)$ are shown by stars, and the large earthquakes $(M>$ 7.0) by circles; the year of occurrences is annotated. The digital seismic stations are shown by green triangles. The model fault plane solution of the 1897 great earthquake is shown (after Bilham and England, 2001). The major tectonic features in the region are indicated; MCT: Main Central Thrust, MBT: Main Boundary Thrust, DF: Dauki Fault, DT: Dapsi Thrust, OF: Oldham Fault, CF: Chedrang Fault, BS: Barapani Shear Zone, KF: Kopili Fault, NT: Naga Thrust, DsT: Disang Thrust, EBT: Eastern Boundary Thrust, Brhm. R.: Brahmaputra River, SP: Shillong Plateau and MH: Mikir Hills. Inset: Map of India showing study region. 


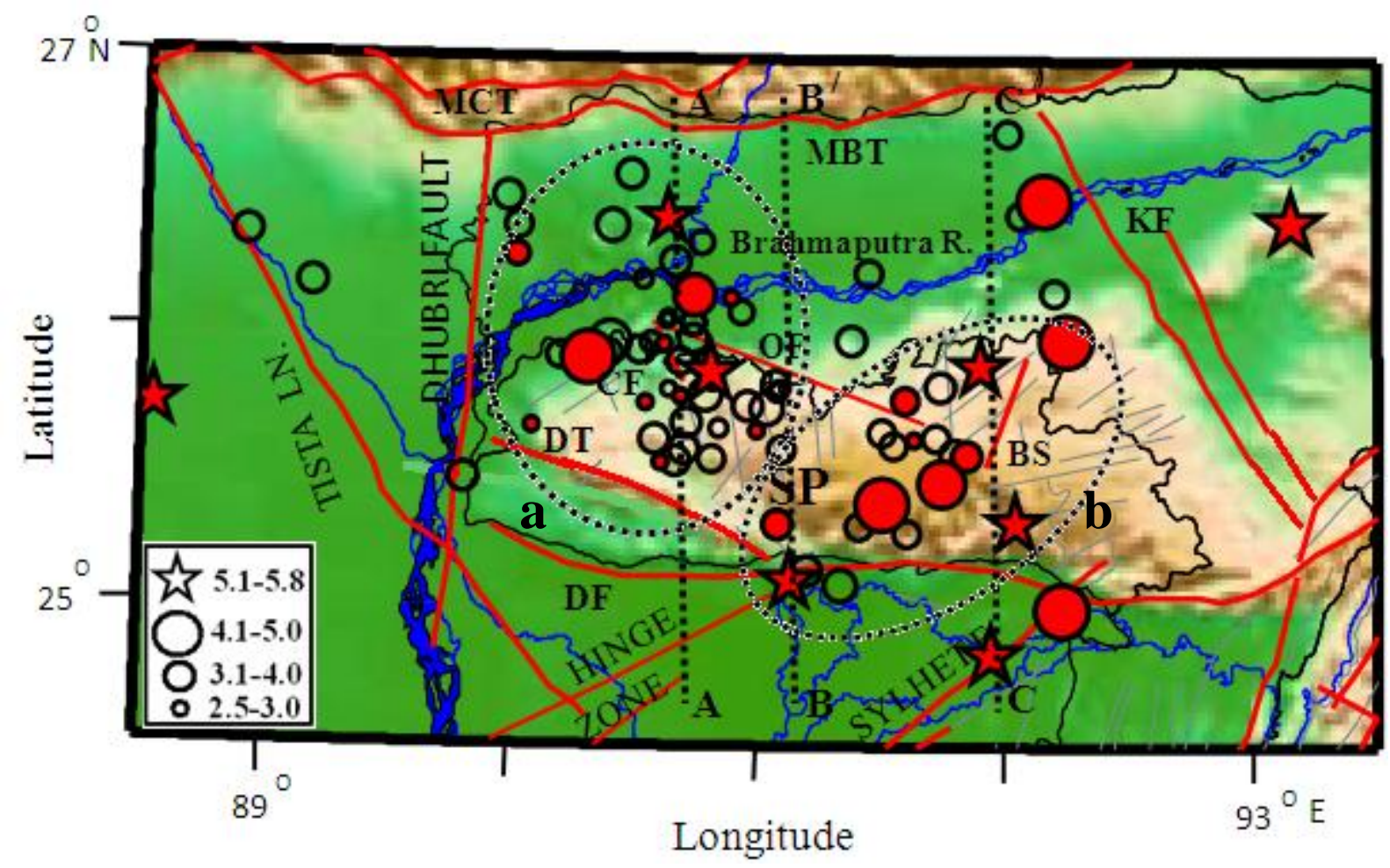

Figure 2. Map showing epicenters of 97 earthquakes used in this study. Solid circles indicate the events of published fault plane solutions, open circles the events of waveform inversion solution in this study. Tectonic features are same as in Figure 1. Two clusters ' $a$ ' and 'b' are shown. A-A', B-B' and $\mathrm{C}-\mathrm{C}^{\prime}$ are three longitude bins along which depth sections are shown in Figure 6 (a), (b) and (c). 


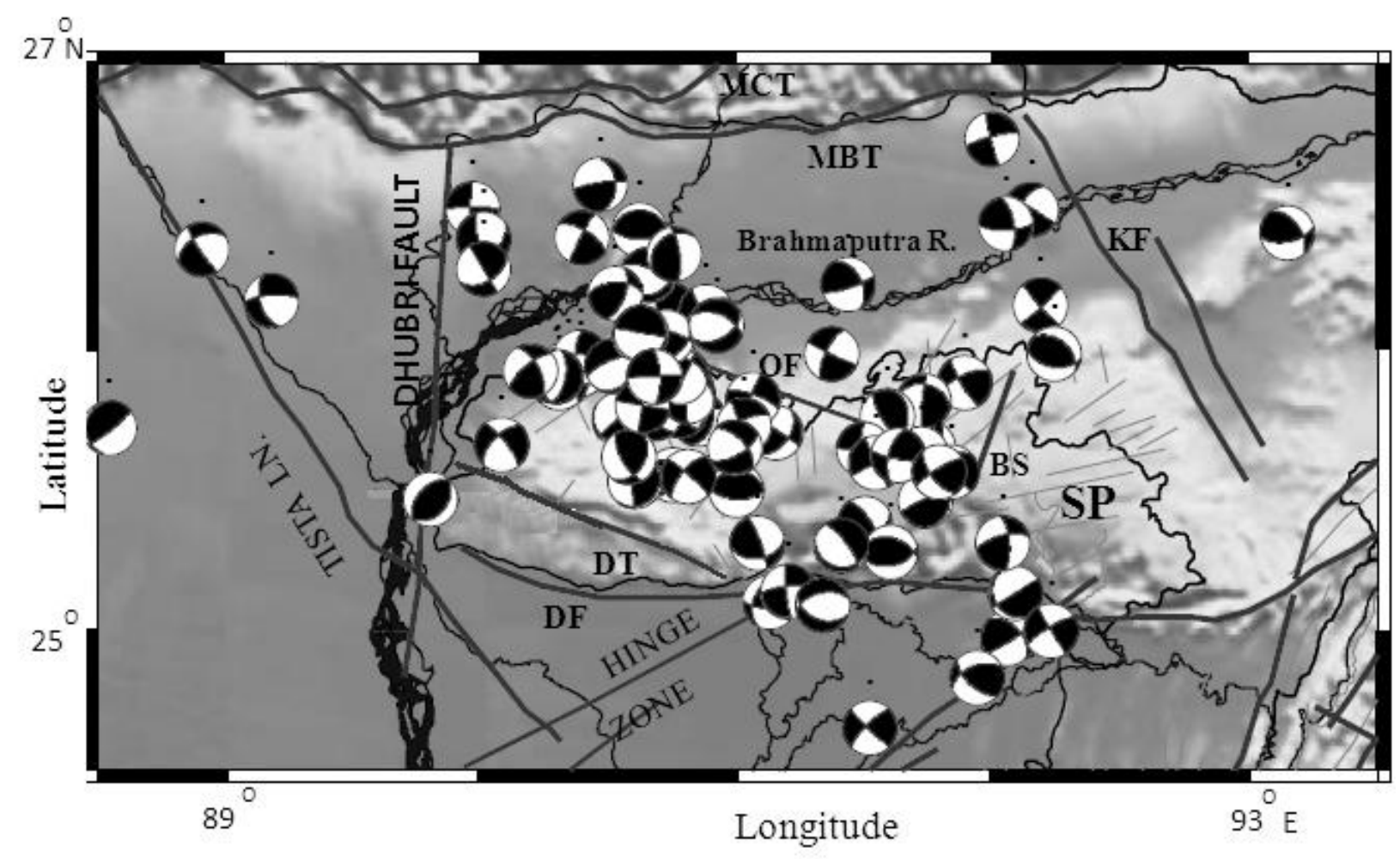

Figure 3. Map showing fault plane solutions of 97 earthquakes in the Shillong plateau; tectonic features as in Figure 1. 

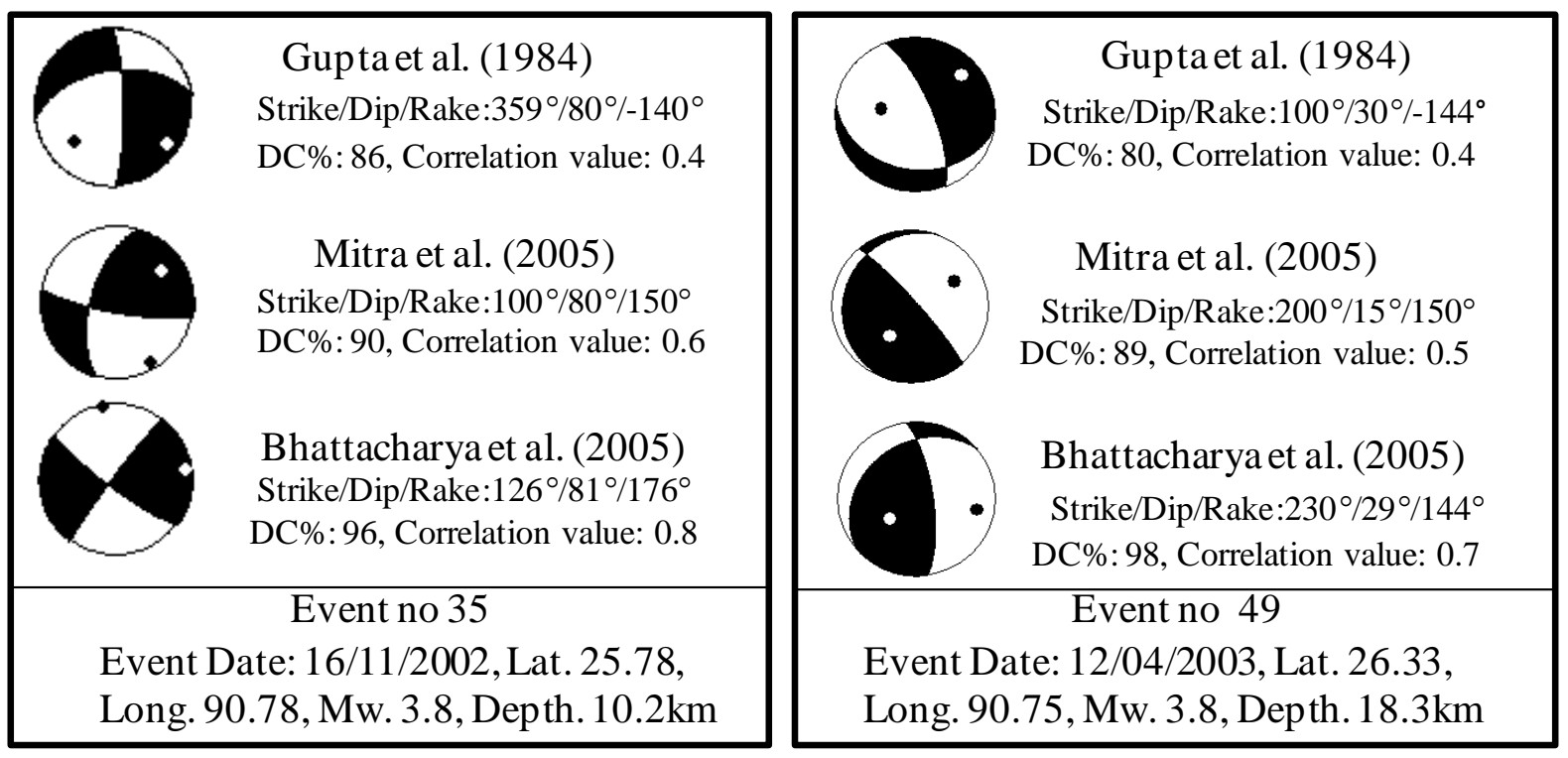

Figure 4. Sensitivity of fault plane solutions tested with three published velocity models (as referred). The velocity model of Bhattacharya et al. (2005) gives the best results for waveform inversion. DC\% stands for Double Couple percentage. 

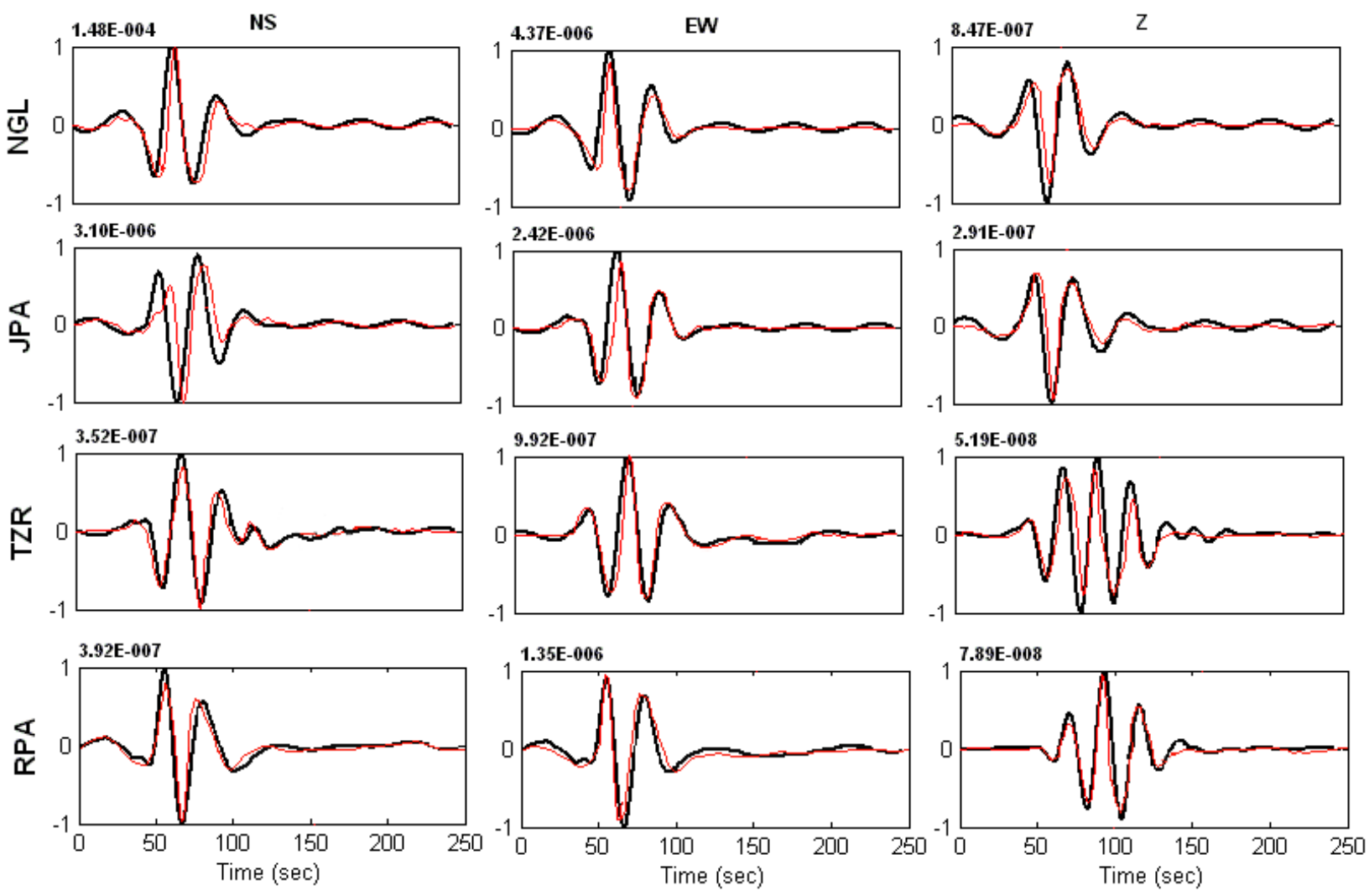

Figure 5(a). Waveform inversion for the event 35 (Table 1); a comparison of synthetic (red curve) and observed (black curve) waveforms at stations NGL, JPA, TZR and RPA for the preferred fault plane solution. $\mathrm{X}$-axis indicates time in sec and $\mathrm{Y}$-axis amplitude in meter. Maximum amplitudes are shown at traces. The inversion results gives strike $126^{\circ}$, dip $81^{\circ}$, rake $176^{\circ}$ and $\mathrm{Mw} 3.6$ for the event. 

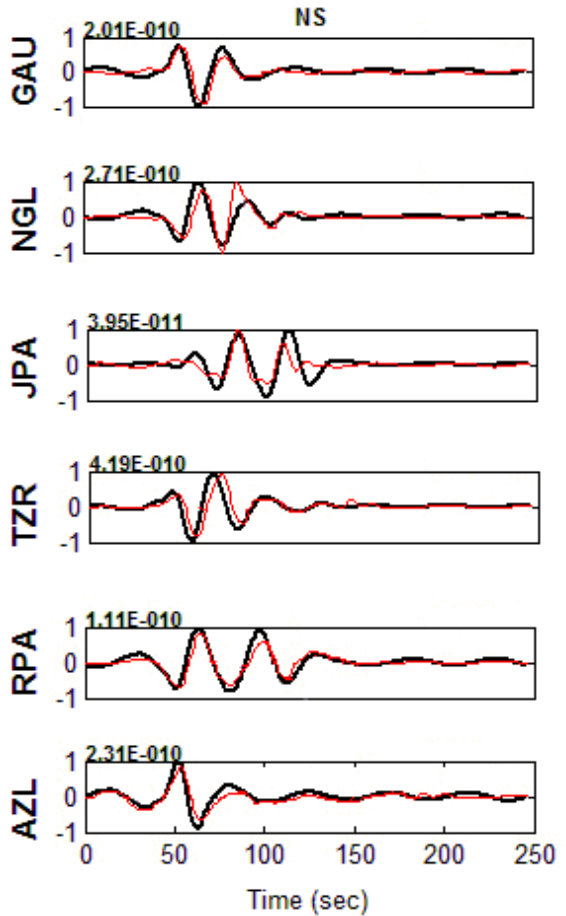
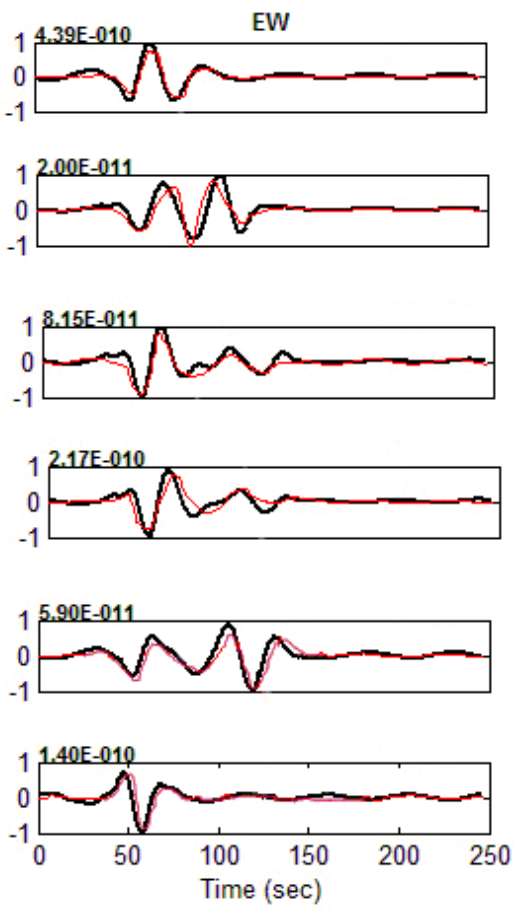
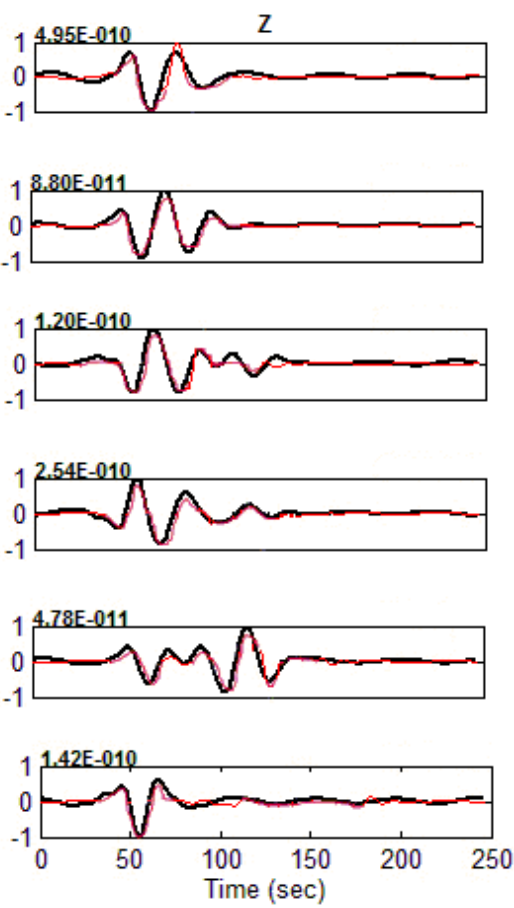

Figure $5(b)$

Figure 5(b). Waveform inversion for the event 49 (Table 1) using data from six stations: GAU, NGL, JPA, TZR, RPA and AZL. The inversion results gives strike $230^{\circ}$, dip $29^{\circ}$, rake $144^{\circ}$ and Mw 3.8 for the event. Other descriptions are same as Figure 5(a). 


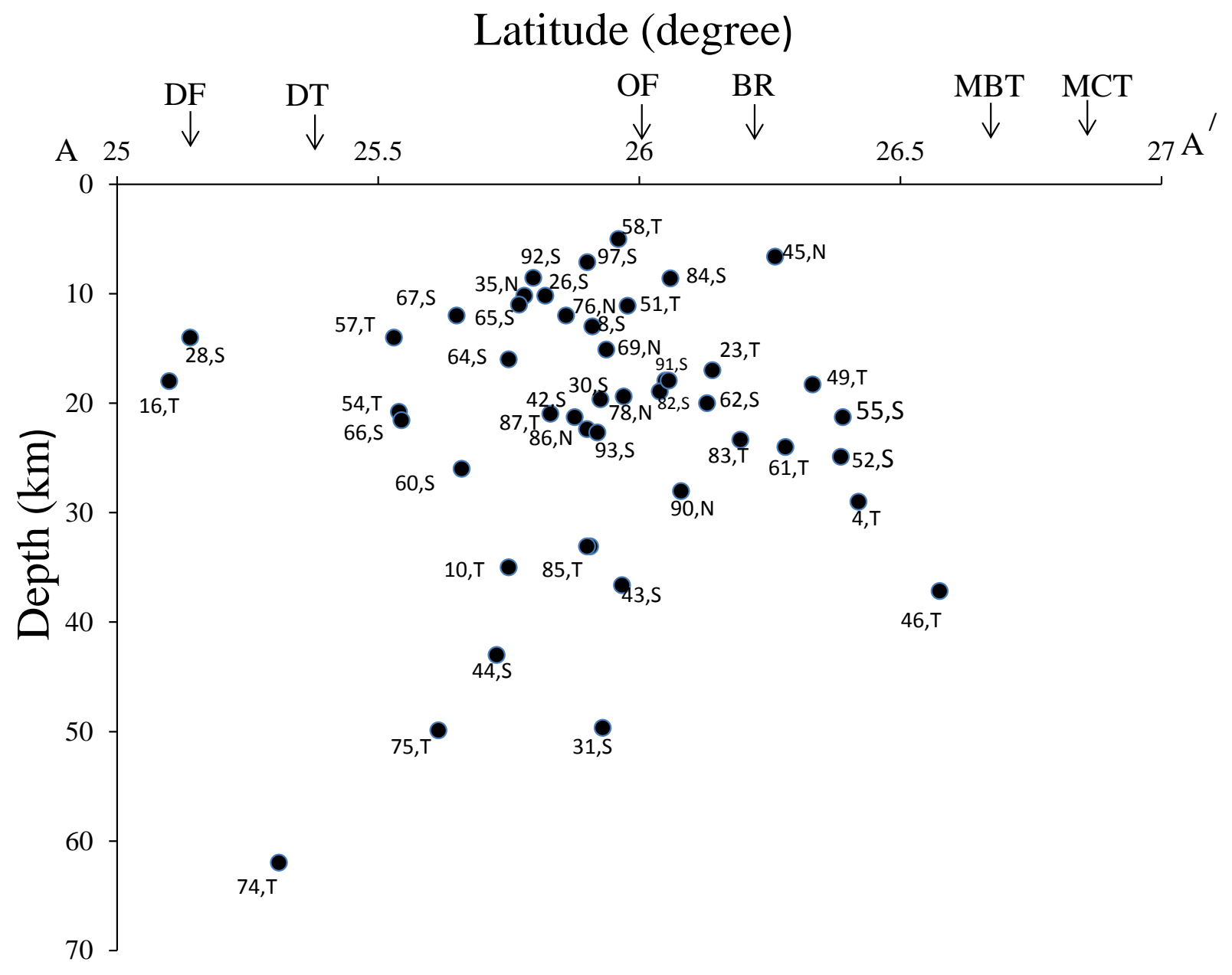

Figure 6(a). Depth section of the earthquakes along A-A (Figure 2); type of solutions are annotated (S: strike slip, T: Thrust, N: Normal). Tectonic features are marked; descriptions as in Figure 1. 


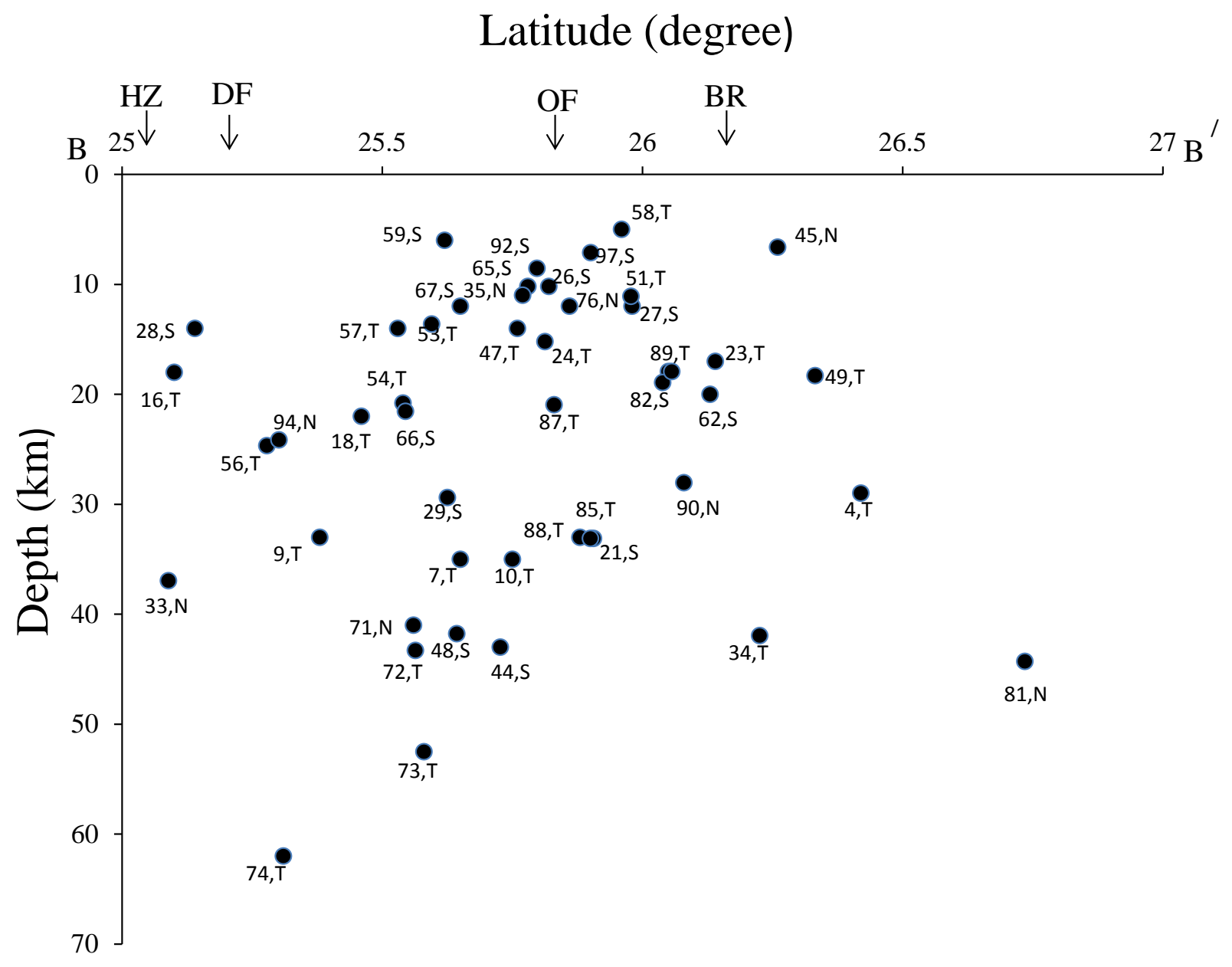

Figure 6(b). Depth section of the events along B-B' (Figure 2).. Other descriptions as in Figure 6a. 


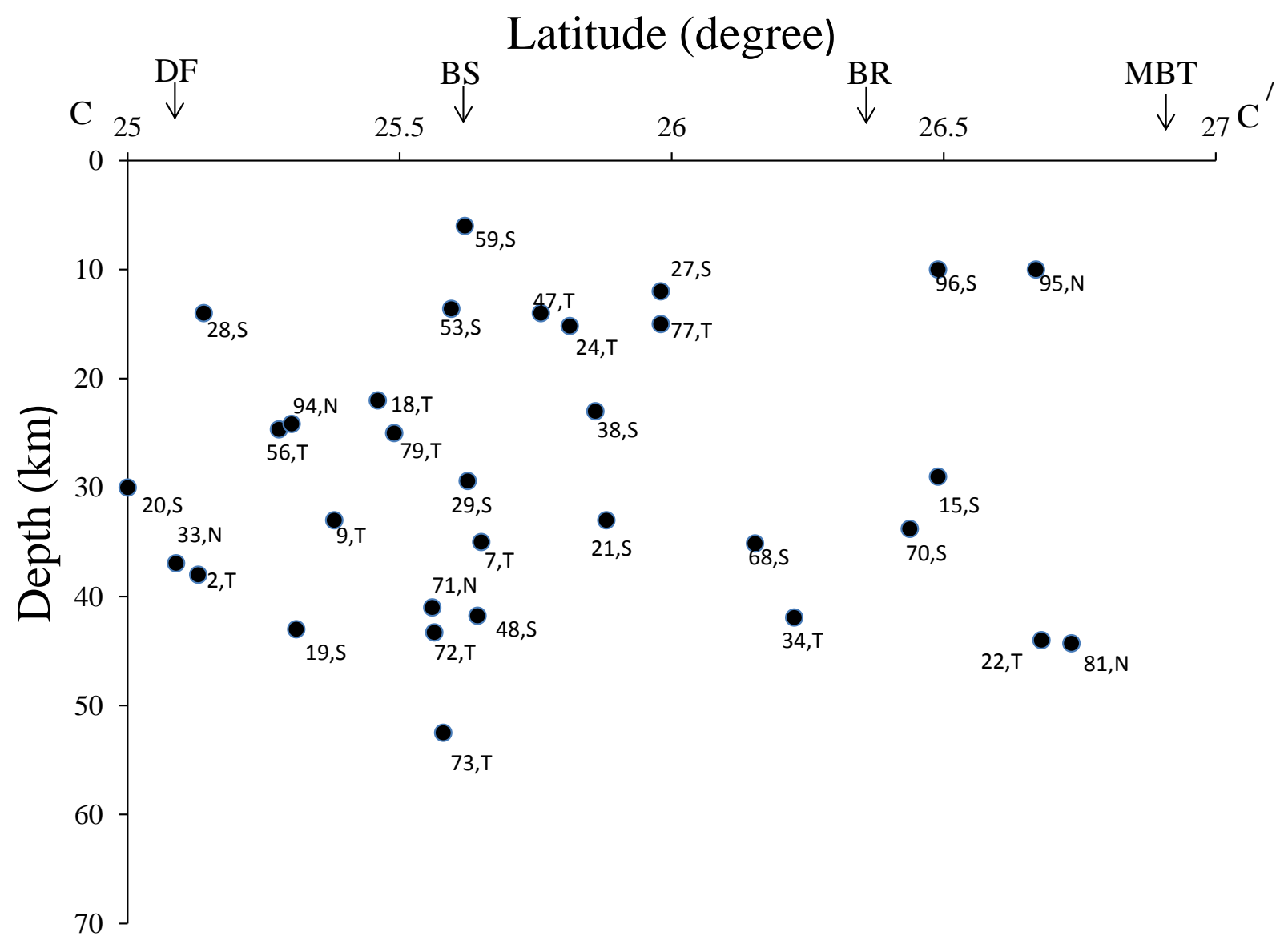

Figure 6(c). Depth section of the earthquakes along C-C' (Figure 2). Other descriptions as in Figure 6a. 

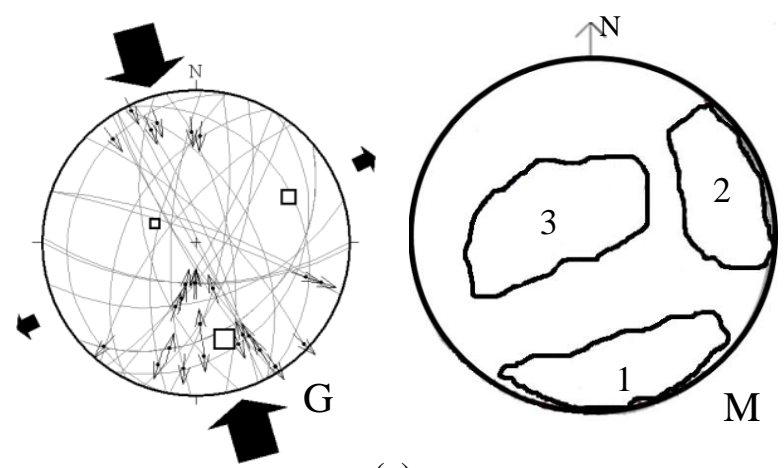

(a)
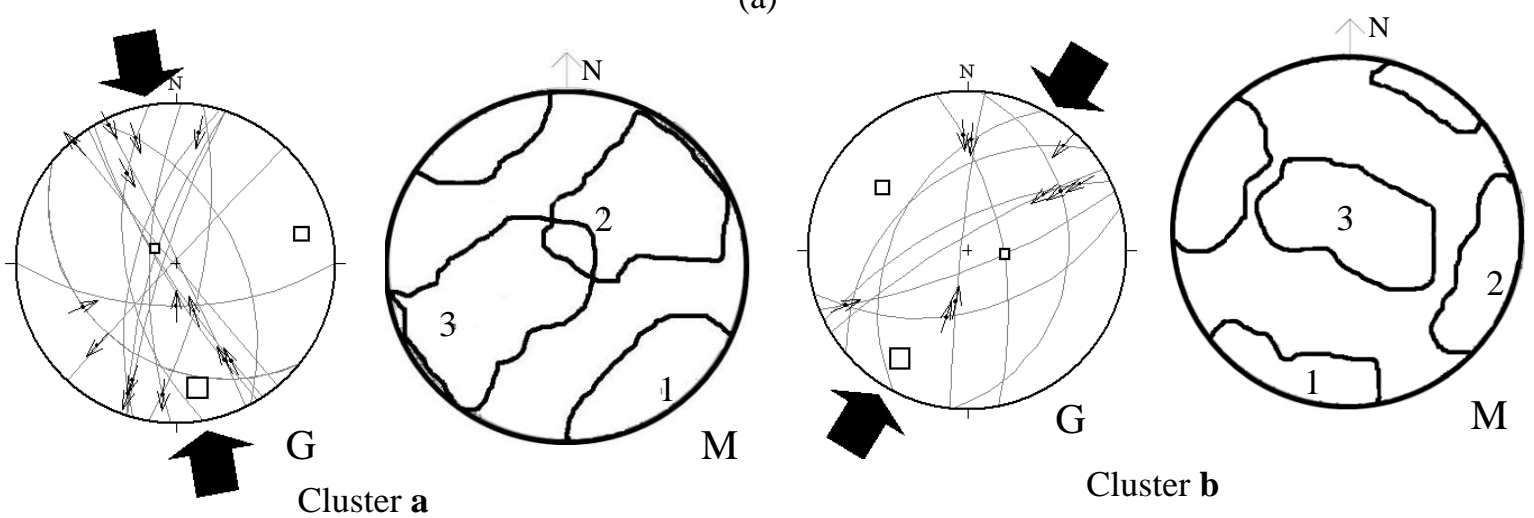

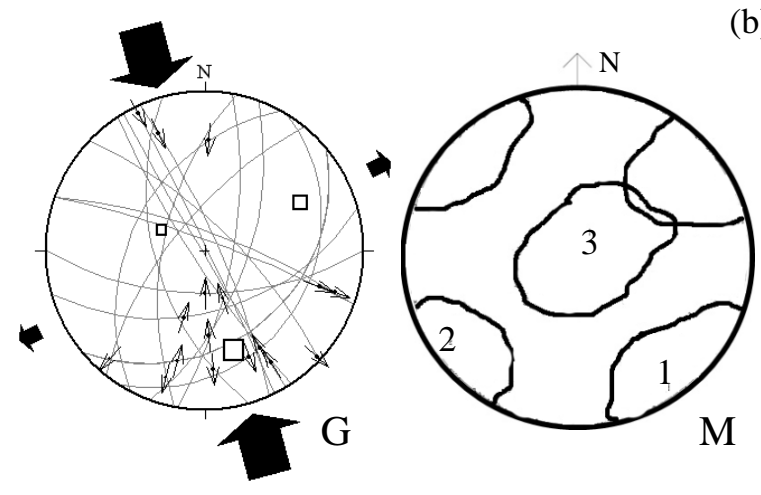

Depth $\leq \mathbf{3 0} \mathbf{~ k m}$

(b)

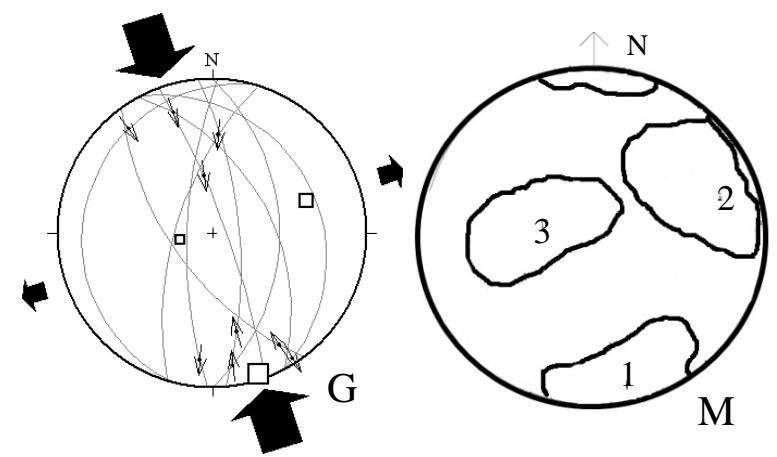

Depth $>\mathbf{3 0} \mathbf{~ k m}$

(c)

Figure 7. Stress tensor inversion results: (a) Shillong plateau, (b) Cluster ' $a$ ' and 'b' and (c) for depth $\leq 30 \mathrm{~km}$ and $>30 \mathrm{~km}$. G and $\mathrm{M}$ denotes the Gauss method and Michael method, respectively. Convergent arrows indicate the direction of maximum principal stress and the divergent arrows indicate the direction of least principal stress in Gauss method. 1, 2 and 3 indicate the maximum, intermediate and least principal axes respectively in Michael method. The $95 \%$ confidence limits are shown by closed contour. 


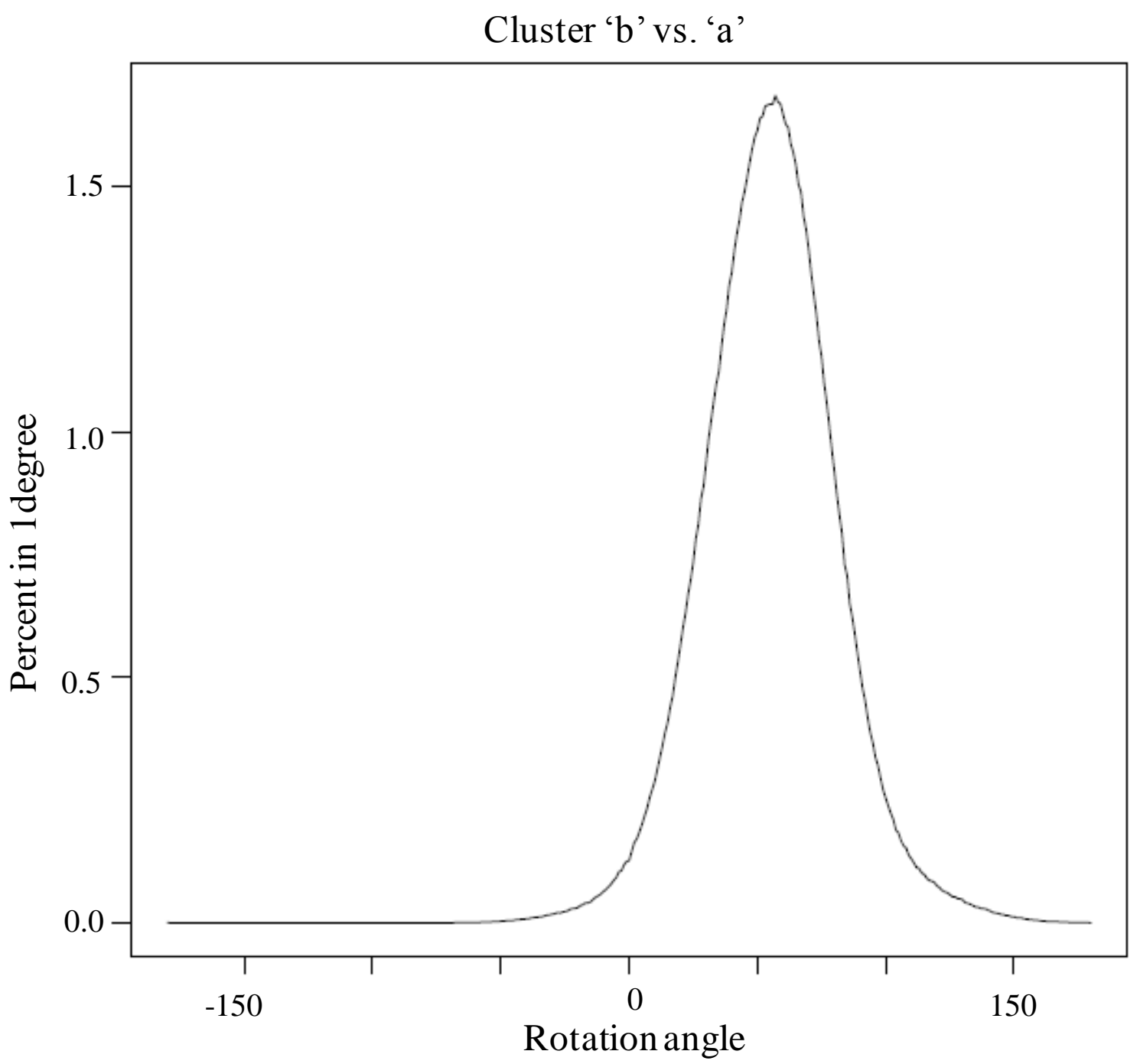

Figure 8. Probability density function of rotation of the compressional stress axis, the clusters ' $b$ ' and ' $a$ '. The vertical axis is the percentage probability that the rotation is within $0.5^{\circ}$ of the point on the horizontal axis. 


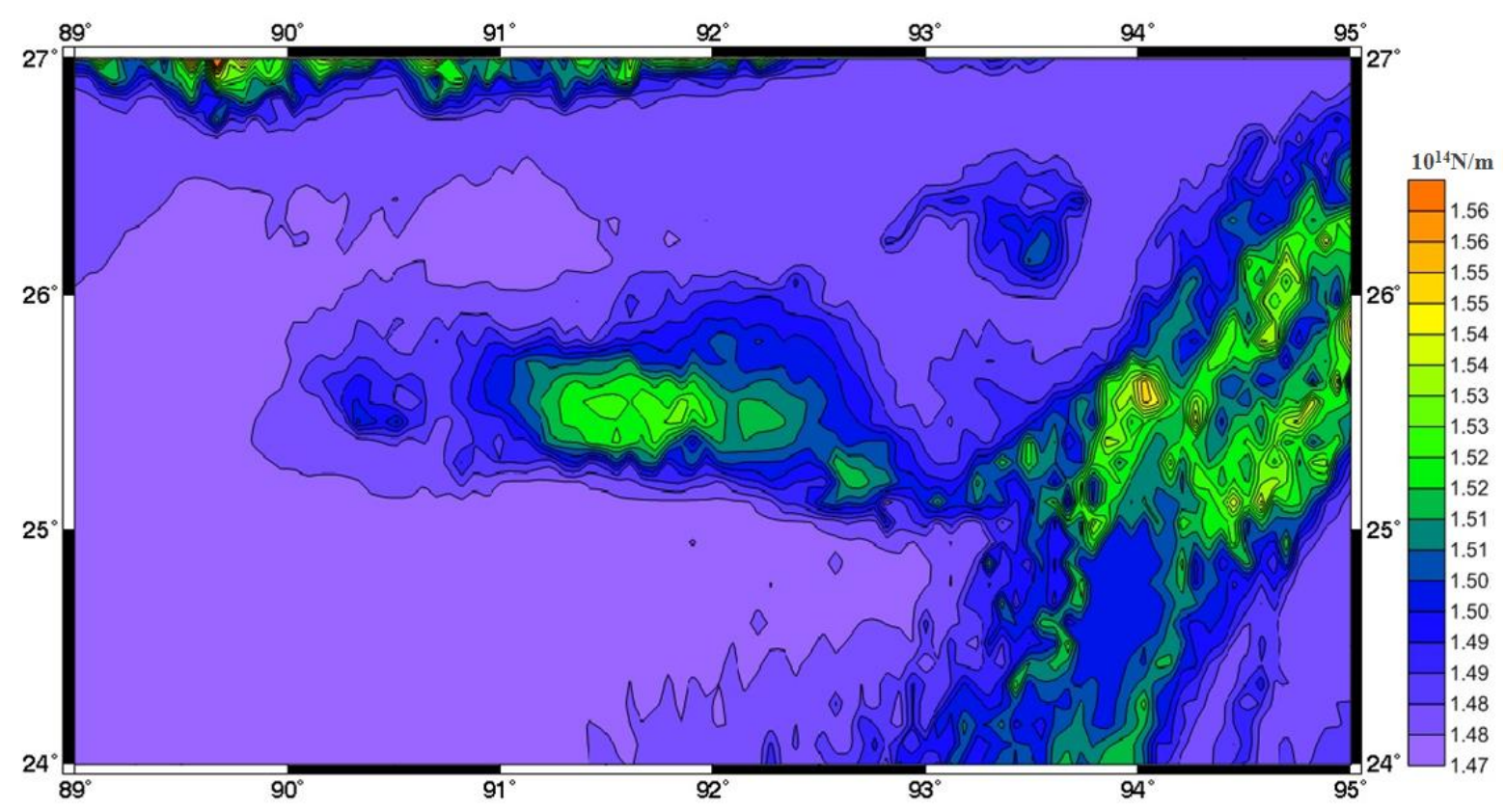

Figure 9. GPE estimated from SRTM 30 and Crust 2.0 model for the Shillong plateau region. The contour interval are at $0.01 \times 10^{14} \mathrm{Nm}$. 


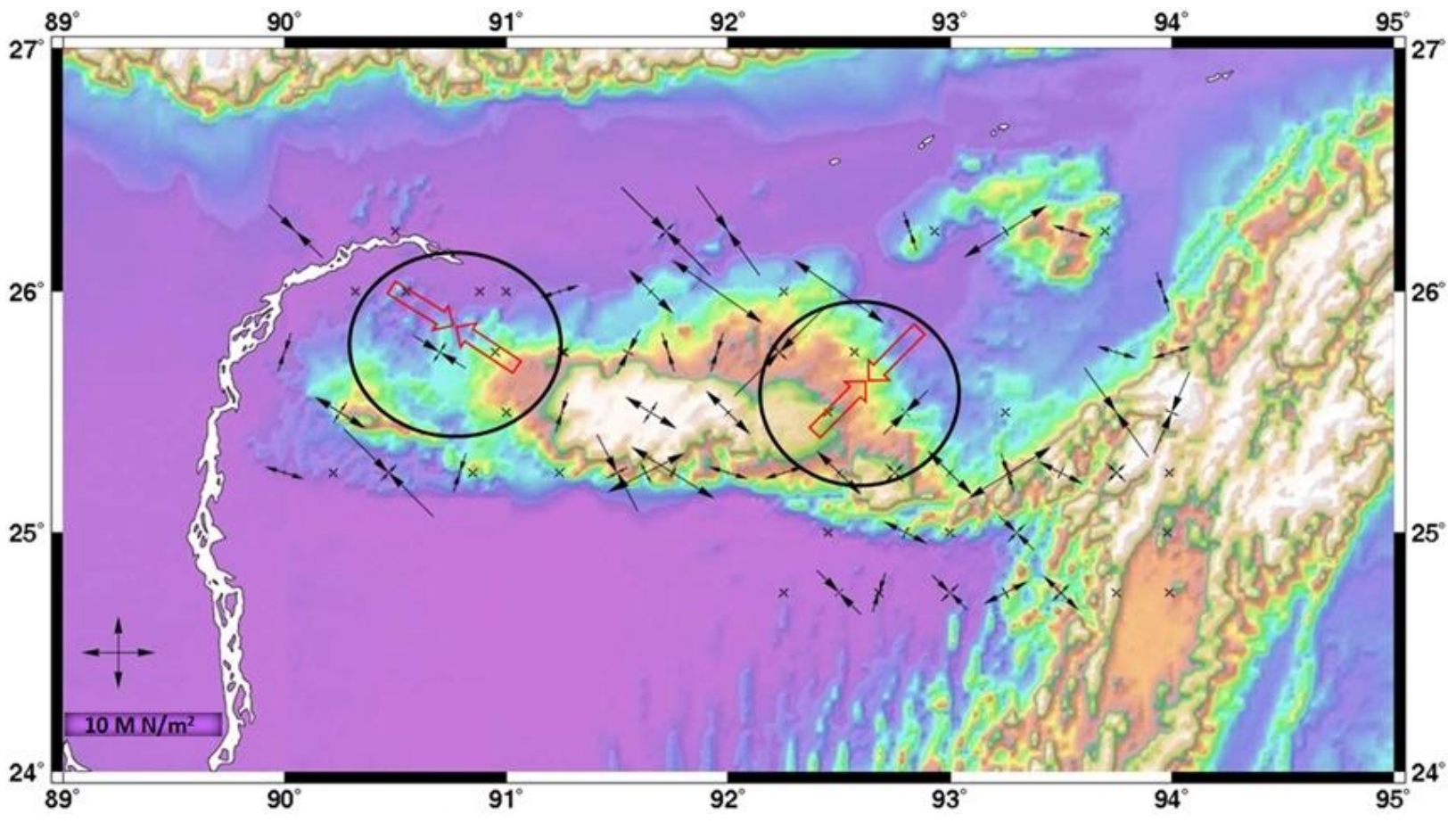

Figure 10. The GPE derived deviatoric stress in the Shillong plateau region. The red arrows in the circles represent the stress pattern corresponding to the clusters "a" and "b" (Fig. 2). The direction of compressive stress in the eastern edge of the plateau is approximately in NE direction while in western edge in NW direction. 


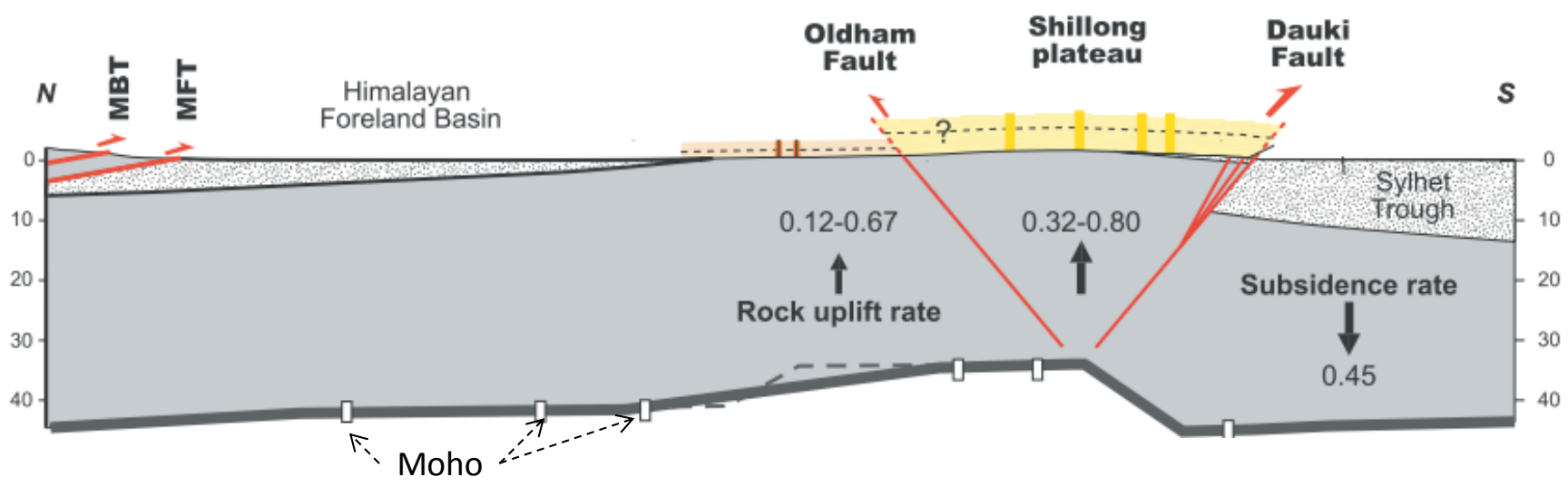

Figure 11. N-S cross section at $91^{\circ} 40^{\prime} \mathrm{E} \pm 10^{\prime}$ after Biswas et al. (2007). The thickness of the sediments in the Sylhet trough is based on work by Shamsuddin and Abdullah (1997). Position and attitude of the Dauki and Oldham faults are after Bilham and England (2001). The position of the Moho (white boxes) is based on data from Mitra et al. (2005). Light brown bars in the yellow zone correspond to the maximum thickness of the sedimentary cover deduced from thermal modeling of AFT data (Apatite and Zircon (U-Th-[Sm])/He) by Biswas et al. (2007). Dashed lines indicate the minimum thickness estimate. The units of different rates are in mm/a (Biswas et al., 2007). 